\title{
Designing Ecological Security Patterns Based on the Framework of Ecological Quality and Ecological Sensitivity: A Case Study of Jianghan Plain, China
}

\author{
Xueping Su ${ }^{1,2} \mathbb{D}$, Yong Zhou ${ }^{1,2, * \mathbb{D}}$ and Qing $\mathrm{Li}^{1,2, * \mathbb{D}}$ \\ 1 The College of Urban \& Environmental Sciences, Central China Normal University, Wuhan 430079, China; \\ suxueping0504@mails.ccnu.edu.cn \\ 2 Key Laboratory for Geographical Process Analysis \& Simulation of Hubei Province, Central China Normal \\ University, Wuhan 430079, China \\ * Correspondence: yzhou@mail.ccnu.edu.cn (Y.Z.); ennstar@mails.ccnu.edu.cn (Q.L.)
}

Citation: Su, X.; Zhou, Y.; Li, Q. Designing Ecological Security Patterns Based on the Framework of Ecological Quality and Ecological Sensitivity: A Case Study of Jianghan Plain, China. Int. J. Environ. Res. Public Health 2021, 18, 8383. https:// doi.org/10.3390/ijerph18168383

Academic Editor: Paul B. Tchounwou

Received: 9 July 2021

Accepted: 5 August 2021

Published: 8 August 2021

Publisher's Note: MDPI stays neutral with regard to jurisdictional claims in published maps and institutional affiliations.

Copyright: (c) 2021 by the authors. Licensee MDPI, Basel, Switzerland. This article is an open access article distributed under the terms and conditions of the Creative Commons Attribution (CC BY) license (https:// creativecommons.org/licenses/by/ $4.0 /)$.

\begin{abstract}
Researchers and managers of natural resource conservation have increasingly emphasized the importance of maintaining a connected network of important ecological patches to mitigate landscape fragmentation, reduce the decline of biodiversity, and sustain ecological services. This research aimed to guide landscape management and decision-making by developing an evaluation framework to construct ecological security patterns. Taking the Jianghan Plain as the study area, we identified key ecological sources by overlaying the spatial patterns of ecological quality (biodiversity, carbon storage, and water yield) and ecological sensitivity (habitat sensitivity, soil erosion sensitivity, and water sensitivity) using the Integrated Valuation of Environmental Services and Tradeoffs (InVEST) model and the Chinese Soil Loss Equation Function. Ecological corridors were obtained by the least-cost path analysis method and circuit theory. A total of 48 ecological sources $\left(3812.95 \mathrm{~km}^{2}\right)$, primarily consisting of water area, forestland, and cropland, were identified. Ninety-one ecological corridors were derived, with a total length of $2036.28 \mathrm{~km}$. Forty barriers and 40 pinch points with the highest improvement coefficient scores or priority scores were selected. There were 11 priority corridors with very high levels of connectivity improvement potential and conservation priority, occupying $16.15 \%$ of the total length of corridors. The overall potential for ecological connectivity is high on the Jianghan Plain. Our framework offers a valuable reference for constructing ecological security patterns and identifying sites for ecological restoration at the regional scale.
\end{abstract}

Keywords: ecological quality; ecological sensitivity; ecological security pattern; ecological corridor; circuit theory

\section{Introduction}

Over the last decade, intensified human activities have accelerated land cover transformation, which has increased land fragmentation, disrupted ecological processes, and caused declines in local biodiversity, ecological services, and ecological environment [1]. Under this background, governments worldwide have taken action in ecological restoration and conservation [2], including China [3]. In 2019, the Ministry of Natural Resources of the People's Republic of China issued a nationwide territory development plan (TDP), which aims to improve people's quality of life and achieve the sustainable development of society by reasonably planning the locations of agricultural production space, urban living space, and ecological space [4]. One of the critical components of the TDP is constructing ecological security patterns (ESPs) [5].

Research on ESPs has come from global studies on ecological networks (ENs), especially from analyses of ENs/greenways in Europe [6] and America [7]. The frameworks for ESP and EN studies are similar-'ecological sources (ESs) — ecological resistance surfacesecological corridors' [8]. Research on ESPs helps ecological conservation by identifying 
important regional areas and critical areas for ecological restoration [5]. Different research backgrounds (e.g., economic status, technical resources, social development status) of EN and ESP studies have led to differences in the understanding of, the evaluation methods used for identifying ecological sources, and the construction of ecological resistance surfaces and ecological corridors. However, in general, EN/ESP studies have been widely recognized due to their contribution to regional health and sustainable development [9]. Studies on ENs in Europe focused on animal conservation [10-16]. The common step is as follows: first, researchers located the potential habitats as ecological sources by identifying migration species' characteristics, especially how the studied species migrated, mated, and found food. Then, researchers chose indicators and parameters for resistance surfaces based on the preferred habitat and behavioral preference of the studied species. Finally, the researchers simulated the migration route of targeted species by analyzing ESs and resistance surfaces of the research area. For example, G. Modica et al. (2021) considered 66 terrestrial faunal focal specie, assessed the habitat quality for each focal faunal species, and mapped the overall habitat quality. Then, they identified the habitat patches and considered the minimum foraging requirements of each focal species and the possibility of animal movement among different patches. According to percolation theory directional and least-cost connectivity analysis, they finally implemented multispecies ecological networks at Calabria [11].

In America, EN/greenway design combines multiple objectives, such as recreational and leisure services, historical and cultural preservation, and ecological protection. Greenways enhance residents' quality of life by contributing to physical health and exercise [17-19]) and providing activity-promoting transportation opportunities that link urban parks and neighborhoods [20]. Regardless of their design and structure, greenways represent "multiple objective, open space corridors that perform natural functions while offering desirable aesthetic qualities to humans as they recreate or commute along trails" [20-22]. Therefore, ecological corridor planning considers the accessibility of ESs and ecological corridors and then designates areas that are close to people, have connectivity, and provide ecological services [7].

Constrained by the concentration of a growing population in urban systems, in China, the construction of ESPs aims to enhance the supply of urban ecosystem services [23] by connecting important ecological areas (mountains, rivers, forests, farmlands, lakes, grasslands, etc.) to ensure the integrity of the structure and function of the ecosystem, which are significant for national and regional ecological security [5]. Ecosystem services comprise 'the ecosystems conditions or processes utilized, actively or passively, to produce human well-being' [24]. Ecosystem services have clear promise to help identify and protect priority areas for biodiversity $[25,26]$. Mapping techniques have provided a powerful tool for integrating complex information related to ecosystem services into landscape management and environmental decision-making [27-29]. Normally, the ecological service system is comprised of three key areas, including the service providing area, service connecting area, and service benefiting area [30,31]. Ecological sources in ESPs studies are similar with the concept of the service providing area but are not totally the same. In the study of ESPs, scholars define ecological sources as places that are important in the ecosystem and provide humans with abundant ecological services or places that are more vulnerable or sensitive to human activities or natural disasters $[5,32,33]$. The ecological corridor in ESP research is defined as an ecological corridor that connects the ecological sources [34-38]. The construction of ecological corridors in ESPs aims to help maintain ecological services, sustain ecological processes, and accelerate species migration [9]. An ESP is a complete EN that can provide ecosystem services with a rational ecosystem structure for the well-being and quality of life of growing populations and for economic and social development. ESPs are important component of national security [39].

In conclusion, unlike EN or greenway research, which focuses only on targeted migrating species (European mode) or focuses on providing ecological corridors for recreation (U.S.A. mode). ESPs in China identify ecologically important areas (high in ecological 
services) and ecologically sensible/vulnerable areas and connect them to maintain and improve ecological services to sustain the development of cities [32].

There are many methods for identifying ecological sources, assigning values to ecological resistance surfaces, and extracting ecological corridors.

There are two main approaches used for ES selection. One method is based on land-cover classification, and the other is multi-indicator ecological evaluation $[16,40]$. Identifying ESs by land-cover type is efficient, simple, but coarse because it does not pay attention to ecological processes, functions, and interactions with the landscape matrix [41]. With the development of society and technology, observation data and field data have become abundant. Multi-indicator evaluations of ecological services and of the ecological sensitivity of land are based on the spatial characteristics of the study area emerged. The indicators selected for ecological evaluation are mainly derived by spatial overlay or model assessment [33]. For example, on the biodiversity function of land, Gao Mengwen et al. (2021) reclassified the slope and vegetation coverage rate and merged them to represent the biodiversity status in the study area [39]. Gao Yang et al. (2020) used the results from the habitat quality model to indicate the biodiversity function [42]. There are also many different assessment methods used to determine water yield and the carbon storage function of land [43]. The accuracy of the results by spatial overlay is relatively low compared with the results derived by model assessment, but spatial overlay methods need fewer data than does model assessment. Researchers normally select evaluation frameworks and indicators according to regional characteristics. For example, according to the ecological problems in Fengxian County (e.g., aggravation of soil and water losses, land desertification and land salinization), Jin et al. (2021) selected soil and water loss sensitivity, desertification sensitivity in plain areas, and salinization sensitivity as the indicators for evaluating ecological sensitivity [44].

Regarding assigning values to ecological resistance surfaces, the most common approach in EN studies is to assign resistance values to different land-cover types based on the migration habits of the targeted species in the study area [11]. However, this is not the case for research on ESPs in popular dense areas in China. Due to the limited allocation of research funds, detailed studies on animal migration habits are rare in urban agglomerations in eastern and central China. Biodiversity in eastern and central China has declined because governments are more focused on economic development [45]. There has been little financial support for wildlife research, and few research teams have conducted detailed surveys of species migration pathways and pattern characteristics in densely populated areas [46,47]. However, without ecological corridors, habitats in densely populated regions remain fragmented. If the status quo is maintained, the ecological function and biodiversity of the area will continue to decline. In this case, when setting the parameter for the resistance surface, researchers who have studied ESPs in densely populated regions have usually derived the parameter by referring to ESP studies on areas with similar climate and natural resources or by assuming parameters based on general animal migration habits $[37,38,48-50]$. Assuming that most animals are sensitive and avoid being close to urban land, a higher resistance value is given to urban land, and a lower resistance value is given to wetlands, grassland, and forest. This assignment is consistent with reality. For example, the nocturnal migration behavior of whooper swans (Cygnus cygnus) is to avoid disturbance by human activity during the day. The probability of wildlife occurrence decreases as the amount of human activity decreases [51]. Birds tend to be close to wetlands/forests because there is less human activity in protected wetlands/forests, and the vegetation in these areas provides food and habitat [52]. However, land-cover types do not reflect all attributes of the land. Based on this shortcoming, Tong et al. (2020) used nighttime lighting data to modify the ecological resistance surface assigned by land-cover classification [53]. In addition to giving ecological resistance to surfaces solely based on land-cover cover types or modified land-cover types, there is a multi-indicator assessment approach [53]. Another commonly used evaluation framework for constructing ecological resistance surfaces is to evaluate ecological resistance from three aspects: topography 
(e.g., slope, altitude), eco-environment (e.g., distance from water bodies, land-cover cover types), and threats from human society (e.g., distance from roads, distance to pollution sources) [54]. The ecological resistance surfaces derived by this evaluation framework are more accurate than those derived solely by land-cover cover type.

Widely used analytical approaches for deriving ecological corridors include least-cost paths (LCPs) [55], circuit theory [56], and graph theory [57,58]. Each approach is designed to meet different objectives and will produce different outcomes. The LCP is the most traditional and commonly used approach, which contiguously collects cells with the lowest cumulative value as the path crosses from one endpoint to the other endpoint. As LCP assumes that individuals have perfect knowledge of the landscape and therefore select a single optimal route, the results of LCP may not be the choice of animals in reality $[59,60]$. In this case, McRae et al. (2008) combined circuit theory from physics with landscape ecology, assuming that the migration process of species in the landscape has electron-like properties, i.e., random flow in a circuit, to identify multiple pathways in the underlying landscape [61]. Circuit theory is based on random-walk theory and results in an implicit assumption that individuals moving across a landscape do not know the relative resistance beyond their immediate surroundings [62]. Graph theory modeling uses habitat patches as points of connection and links as corridors. This approach could be combined with LCP modeling or circuit theory to derive corridors and habitat patches [63]. In conclusion, the circuit model more accurately approximates how individuals move through real landscapes. This model is useful for evaluating connectivity and identifying constrained areas (bottlenecks) for possible conservation action [64].

Recently, research on ESPs has mainly used counties or cities as the research area. These studies are practical because they can be integrated into the regional spatial planning of that county or city. However, these studies have not considered the integration of ecosystems. For example, if one of the ESs in county A is in the radiation of one of the ESs in county B, those studies failed to derive. Therefore, the study of ESPs is better focused on a complete physical geographic landscape than on an administrative unit. The primary objective of our study was to present a comprehensive approach framework for constructing ESPs and identifying key points for ecological conservation and ecological restoration. In this study, we calculated the resistance surface of the research area based on the characteristics of wildlife on the Jianghan Plain by referring to other studies (Figure 1). Then, we derived ecological corridors between each ecological source on the Jianghan Plain based on least-cost analysis and circuit theory using Circuitscape 4.1. We identified the important barriers for improving habitat connectivity, determined which areas should be prioritized, and calculated the network centrality of ESs and corridors. The combination of graph theory modeling and circuit theory modeling could quantify the potential corridors and habitat patches that may help land managers to prioritize units that should receive more protection $[56,65]$. This objective was partitioned into four subobjectives: (1) identify the key ecological space in the Jianghan Plain based on the assessment of ecological quality and ecological sensibility, (2) model potential corridors and construct ESPs and prioritize corridors according to their relative importance and the effect of each corridor on global connectivity, (3) identify the key locations where conserving ecological functions and improving ecological connectivity should be conducted, and (4) assess the robustness. The novelty of this study lies in that it not only synthesizes important and targeted ecosystem services and ecological sensitivity indicators at the regional scale to systematically assess ecological status and construct an ESP but also considers which ecological corridors and sites should be better protected or where it is necessary for a site's ecological functions to be restored to improve landscape connectivity [29]. 


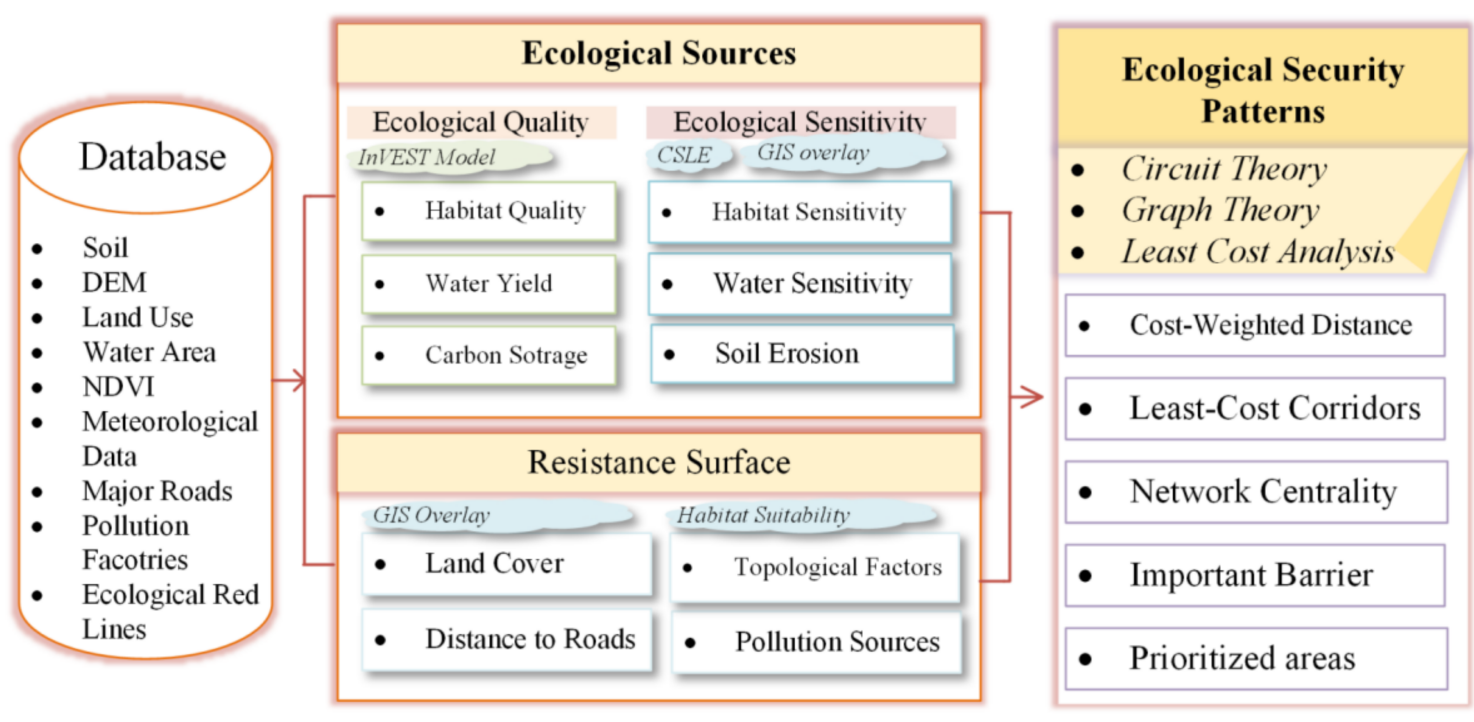

Figure 1. Research framework.

\section{Materials and Methods}

\subsection{Study Area and Data Sources}

\subsubsection{Study Area}

Jianghan Plain comprises 22 counties (Figure 2). The total area is $41,828.28 \mathrm{~km}^{2}$. The study area covers mainly cropland, accounting for $61.75 \%$ of its total area. The rest of the land use areas are forestland $(16.26 \%$ of the total area), water bodies $(13.27 \%)$, urban or built-up $(7.95 \%)$, grassland $(0.36 \%)$, and barren land $(0.41 \%)$. Forestland is mainly distributed in Daba Mountain in Dangyang County and Dongdao County and Dahong Mountain in northern Jingshan County and Zhongxiang County.

The Jianghan Plain, with its dense network of rivers, was a complete wetland ecosystem in prehistoric times, but over the past 2000 years, under the influence of human activities, its natural wetland landscape gradually transformed into a farmland landscape. In the 13th century, the river was cleared of wetlands and forest swamps, and the dominant waterfowl populations were traditionally geese and cranes. At that time, waterfowl (feathers), ivory, and rhinoceros skin (leather) were the main economic resources of Chu. At the end of the 17th century, the final abolition of the "river and lake office", a fishing tax institution in the Jianghan Plain, marked the decline in river, lake, and wetland areas due to the cultivation of lakes and fields. Short-tailed albatross (Diomedea albatrus) and spotted-billed pelican (Pelecanus roseus) were once widely distributed here before the mid-19th century but are now nearly extinct [66-68].

Existing common animals include birds such as the white stork (Ciconia ciconia), black stork (Ciconia nigra), great bustard (Otis tarda), Reeves' pheasant (Syrmaticus reevesii), owls (Strigiformes), black-faced spoonbill (Platalea minor) [69]; mammals such as the dhole (Cuon alpinus), porcupine, and hog badger (Arctonyx collaris) [70]; and amphibians such as the Chinese giant salamander (Andrias davidianus) and great tree frog (Zhangixalus dennysi) [71]. The behavioral activities of these animals are sensitive to the quality of human activities and the natural environment. Therefore, the trade-off between economic development and ecological conservation requires a sustainable spatial plan for natural resource management. 


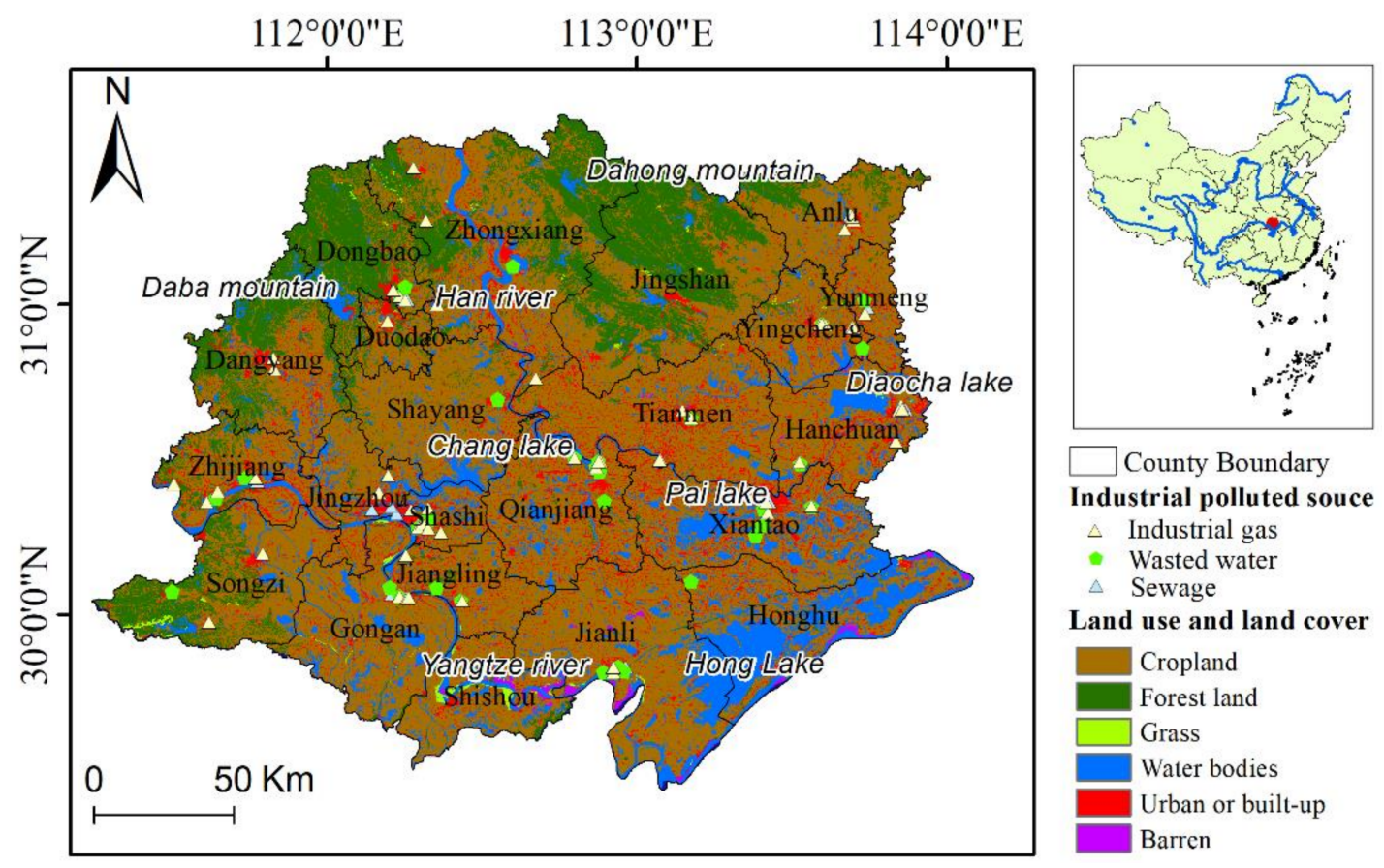

Figure 2. Land use and land cover in the Jianghan Plain.

\subsubsection{Data Sources}

The data sources of this paper are described in Table 1 . The ecological red line of Hubei is the protected natural area in Hubei.

Table 1. Data description.

\begin{tabular}{|c|c|c|c|}
\hline Data Name & Data Source & Time & Units/Resolution \\
\hline $\begin{array}{c}\text { Depth to bedrock map of } \\
\text { China }\end{array}$ & Scientific data [72] & 2018 & $100 \mathrm{~m} \times 100 \mathrm{~m}$ \\
\hline Soil types & $\begin{array}{l}\text { Harmonized World Soil Database version } 1.2 \\
\text { (HWSD V1.2) [73] }\end{array}$ & & $1: 1,000,000$ \\
\hline Land-use/land cover data & $\begin{array}{l}\text { Resource and Environment Science and Data } \\
\text { Center [74] }\end{array}$ & 2020 & $30 \mathrm{~m} \times 30 \mathrm{~m}$ \\
\hline Ecological red line of Hubei & $\begin{array}{c}\text { Department of Natural Resource of Hubei } \\
\text { Province }\end{array}$ & 2020 & $1: 250,000$ \\
\hline Road & Baidu Map; Open Street Map & 2020 & $1: 250,000$ \\
\hline Meteorological data & $\begin{array}{l}\text { Meteorological Data Center of China } \\
\text { Meteorological Administration [75] }\end{array}$ & 2019 & Daily \\
\hline Digital elevation model & Shuttle Radar Topography Mission [76] & 2008 & $30 \mathrm{~m} \times 30 \mathrm{~m}$ \\
\hline $\begin{array}{l}\text { List of pollution factories in } \\
\text { Hubei, } 2017\end{array}$ & $\begin{array}{l}\text { Department of Ecological and Environment } \\
\text { of Hubei Province; Ovitalmap. }\end{array}$ & 2017 & \\
\hline
\end{tabular}

\subsection{Research Framework}

\subsubsection{Identifying Ecological Sources}

While ecosystem services are often provided by large natural ecosystems (mountains, forests, rivers, etc.), they are also supplied in urban ecosystems [53]. The goal of ESPs is to increase ecological connectivity and optimize land use/landcover (LULC) arrangements in selected region which can maximise the local supply of ecosystem ser-vices [77]. ESs are an important part of ESPs because they are starting points or destinations of organisms, materials, energy, and information flow [35]. 
Based on the notions of ecological connectivity [29], multifunctionality of ecosystems and maximization of benefits for both humans and natural conservation [78-80], we synthesized the complex ecological problems and specific ecological significance of metrics using three key ecosystem services and three ecological sensitivity indicators $[35,79,80]$. These indicators are popular in ecosystem assessment research [81]. Habitat, the key element of ecology, is related to biodiversity. The higher the quality of the habitat is, the more biodiversity can be preserved. Habitat quality directly influences ecological functions and ecological services, impacting multiple ecological processes, e.g., pollination and nutrient cycles [13,82]. Landscape fragmentation in the Jianghan Plain is serious due to rapid urban sprawl, which poses a threat to wildlife habitat [83]. As one of the important regulatory functions of terrestrial ecosystems, carbon sequestration plays a substantial role in climate regulation [84]. The Jianghan Plain is in the north-south climate transition zone, with ample rainfall, sunshine, and heat resources. There are abundant wetlands, forests, grasslands, and water bodies [85]. Therefore, land cover with high carbon sequestration ability should be better protected [86]. Water is an essential part of life. After the implementation of the South-to-North Water Diversion Project, the total amount of water released from the Danjiangkou Reservoir decreased, and the infrastructure at the main diversion gates and river diversions in the middle and lower reaches of the Han River deteriorated, reducing the water supply for agricultural production $[87,88]$. Water yield is also an important regulative ecological service on the Jianghan Plain. In conclusion, we took habitat quality, carbon storage, and water yield as three indicators as the main eco-system services and quantified them by the InVEST model.

Ecological sensitivity is another principal factor for identifying potential eco-environmental problems. Natural reserves are sensitive and vulnerable to high-intensity human activity. Ecological red lines are the primary category of protected regions in China, providing individuals and populations with natural resources, habitats and ecological services. By the end of 2018, 40 national nature reserves and 39 provincial natural reserves and other important wildlife habitats (e.g., forest parks, wetlands) were widely distributed in the Jianghan Plain [89]. In addition, water is a fundamental resource for regional economic and social development, and a water sensitivity assessment is required because of the double effect of waste and pollution [90]. Furthermore, soil erosion is a severe problem affected by heavy precipitation during spring and summer and the high intensity of construction. Therefore, we selected three ecological sensitivity indicators: habitat sensitivity, water sensitivity, and soil erosion sensitivity. The three indicators were computed using GIS spatial overlap analysis and the Chinese soil loss equation (CSLE).

We normalized the integrated ecological service and ecological sensitivity by the max-min method, gave them equal weight, and combined them to obtain the ecological importance map. Then, we considered the ecological red line (the national protected reserves). Given the lower radiation and weak connectivity of small patches [50], the source patches with an area less than $10 \mathrm{~km}^{2}$ were removed from ecological sources

\subsubsection{Ecological Services Habitat Quality}

Habitat quality in the InVEST model refers to the ability of the landscape to pro-vide conditions appropriate for individual and population persistence. The model em-phasizes landscape diversity and the corresponding landscape quality. This approach analyzes the relative effect of each threat, the relative sensitivity of each habitat type to a threat, the distance between habitats and threat sources, and the degree to which the land is legally protected [91]. The habitat quality score ranges from 0 to 1 . A higher re-gional habitat quality value will receive a higher score. 
By referring to previous research [83], we chose urban, rural residential, other construction land, arable land, main roads, and railroads as the anthropogenic threat fac-tors of habitats. Additionally, we selected arable land, forest, grassland, water bodies, and unused land as natural habitats for different creatures. The parameters for the model are provided in Appendix A (Table A1). The impact $i_{r x y}$ of threat $r$ from grid cell $y$ on the habitat in grid cell $x$ is represented by the following equations:

$$
\begin{gathered}
i_{r x y}=1-\left(\frac{d_{x y}}{d_{r \max }}\right) \text { if linear } \\
i_{r x y}=\exp \left(-\left(\frac{2.99}{d_{r \max }}\right) d_{x y}\right) \text { if exponential }
\end{gathered}
$$

where $i_{r x y}$ is the impact of threat $r$ in raster $y$ on habitat $x, d_{x y}$ is the linear distance between grid cells $x$ and $y$, and $d_{r \max }$ is the maximum effective distance of the threat.

$D_{x j}$ gives the total threat level in grid cell $x$ with land use/land cover (LULC) or habitat type $j$ and is calculated as follows:

$$
D_{x j}=\sum_{r=1}^{R} \sum_{y=1}^{\gamma_{r}}\left(\frac{W_{r}}{\sum_{r=1}^{R} W_{r}}\right) r_{y} i_{r x y} \beta_{x} S_{j r}
$$

where $D_{x j}$ is the habitat degradation or total threat level in grid cell $x$ with LULC or habitat type $j, R$ is the number of threat factors, $r$ represents the threat layer, and $Y_{r}$ indicates the set of grid cells on $r^{\prime}$ s raster map. $W_{r}$ indicates the weight of each threat factor (value range from 0 to 1$). r_{y}$ indicates the effect of threat $\mathrm{r}$ that originates in grid cells; $i_{r x y}$ indicates the distance between habitat and the threat source and the impact of the threat across space; $\beta x$ is the factor that mitigates the impact of threats on habitat by environmental policies (here, $\beta x=1$ ); $S_{j r}$ indicates the sensitivity of LULC type $j$ to threat factor $r$; the weights of threats are normalized so that the sum across all threat weights equals 1 . By normalizing weights such that they sum to 1 , we can think of $D_{x j}$ as the weighted average of all threat levels in grid cell $x$. The map of $D_{x j}$ will change as the set of weights we use changes.

A grid cell's degradation score is translated into a habitat quality value using a halfsaturation function where the user must determine the half-saturation value; furthermore, as a grid cell's degradation score increases, its habitat quality decreases.

$$
Q_{x, y}=H_{j}\left(1-\left(\frac{D_{x, j}^{z}}{D_{x, j}^{z}+K^{z}}\right)\right)
$$

where $Q_{x, y}$ is the quality of habitat in parcel $x$ that is in LULC $j ; H_{j}$ indicates the habitat suitability of LULC type $j ; k$ is the half-saturation constant; $z=2.5$. More details of this model can be found in the InVEST user's guide [91].

\section{Water Yield}

The freshwater supply is represented as the water yield and derived from the InVESTWater Yield model. The InVEST-Water Yield model estimates the annual average quantity of water produced by a watershed. The water yield in InVEST is defined as the amount of water lost from the landscape, and it calculates the sum and averages of the water yield based on the principle of water balance at the sub-watershed level [91,92]. The annual water yield $Y(x)$ for each pixel on landscape $x$ is determined as follows:

$$
Y(x)=\left(1-\frac{A E T(x)}{P(x)}\right) P(x)
$$

where $A E T(x)$ is the actual annual evapotranspiration for pixel $x$, and $P(x)$ is the annual precipitation on pixel $x$. The parameters are presented in Appendix A (Table A1). 


\section{Carbon Storage}

Soil carbon sequestration relates to the climate, plants, and agriculture. The carbon storage model in InVEST uses a land-cover map to estimate the amount of carbon storage in a landscape. The total carbon storage $\mathrm{C}\left(\mathrm{t} . \mathrm{ha}^{-1}\right)$ equals the sum of the carbon stock in four carbon pools (aboveground biomass, belowground biomass, soil, and dead organic matter) $[93,94]$. The parameters are presented in Appendix A (Table A1).

\subsection{Ecological Sensitivity}

\subsubsection{Habitat Sensibility}

Habitat sensibility was derived by overlaying the score of land-cover type, the normalized difference vegetation index (NDVI), distance to major roads, and distance to ecological red lines $[93,94]$ (Table 2). The higher the habitat sensibility place is, the higher the score it will obtain.

Table 2. The standard for habitat sensibility score.

\begin{tabular}{cccccc}
\hline & Score & $\mathbf{7}$ & $\mathbf{5}$ & $\mathbf{3}$ & $\mathbf{1}$ \\
\hline & Distance to major road $(\mathrm{m})$ & {$[0,1000)$} & {$[1000,2000)$} & {$[2000,3000)$} & {$[3000,+\infty)$} \\
\cline { 2 - 6 } $\begin{array}{c}\text { Habitat } \\
\text { Sensibility }\end{array}$ & $\begin{array}{c}\text { Distance to natural } \\
\text { reserves }(\mathrm{m})\end{array}$ & {$[0,3000)$} & {$[3000,6000)$} & {$[6000,9000)$} & {$[9000,+\infty)$} \\
\cline { 2 - 6 } & land-cover type & $\begin{array}{c}\text { Forestlands; water } \\
\text { bodies; wetland }\end{array}$ & Grass; cropland & Barren & Urban or built-up \\
\cline { 2 - 7 } & NDVI & {$[0.7,1]$} & {$[0.5,0.7)$} & {$[0.3,0.5)$} & {$[0,0.3)$} \\
\hline
\end{tabular}

\subsubsection{Water Sensibility}

Water sensibility is affected by the distance to the water area and water pollution source (Table 3) $[88,89]$. We found the list of wastewater discharge plants, sewage treatment plants, and pollution gas emission plants published online by the Hubei Environmental Protection Bureau and located each plant by Ovitalmap software. The places closer to the water area and pollution source had a higher water sensibility [88].

Table 3. The standard for water sensibility score.

\begin{tabular}{cccccc}
\hline & Score & $\mathbf{7}$ & $\mathbf{5}$ & $\mathbf{3}$ & $\mathbf{1}$ \\
\hline \multirow{3}{*}{ Water sensibility } & Distance to rivers, lakes, etc. $(\mathrm{m})$ & {$[0,500)$} & {$[500,1000)$} & {$[1000,1500)$} & {$[1500,+\infty)$} \\
\cline { 2 - 6 } & $\begin{array}{c}\text { Distance to wastewater sources or } \\
\text { sewage treatment plant }(\mathrm{m})\end{array}$ & {$[0,3000)$} & {$[3000,6000)$} & {$[6000,9000)$} & {$[9000,+\infty)$} \\
\cline { 2 - 6 } & $\begin{array}{c}\text { Distance to polluting air } \\
\text { sources }(\mathrm{m})\end{array}$ & {$[0,4000)$} & {$[4000,8000)$} & {$[8000,12000)$} & {$[12000, \infty)$} \\
\hline
\end{tabular}

\subsubsection{Soil Erosion Sensitivity}

Researchers around the world use the soil erosion index to measure the effectiveness of soil conservation [95]. Soil erosion changes the landscape, disrupts the carbon cycle at multiple scales, and reduces crop yield and biomass production [96]. The higher the soil erosion is, the lower the amount of soil conserved is. The most common models employed for soil erosion assessment are the Soil and Water Assessment Tool (SWAT) model, the Revised Universal Soil Loss Equation (RUSLE) model [95], and the CSLE [97]. Each model has its drawbacks and strengths. The RUSLE model is effective for large-region 
evaluations [95], and the CSLE is more suitable for soil erosion studies in China [97]. In this study, we used the CSLE as the following equation:

$$
\mathrm{A}=\mathrm{R} \times \mathrm{K} \times \mathrm{LS} \times \mathrm{C} \times \mathrm{P} \times \mathrm{T}
$$

where $\mathrm{A}$ is the soil loss in tha $\mathrm{a}^{-1} \mathrm{yr}^{-1} \cdot \mathrm{R}$ is the rainfall erosivity in MJ.mm.ha ${ }^{-1} \cdot \mathrm{h}^{-1} \cdot \mathrm{yr}^{-1}$. $\mathrm{K}$ is the soil erodibility in t.h. $\mathrm{MJ}^{-1} \mathrm{~mm}^{-1}$. $\mathrm{L}$ and $\mathrm{S}$ are dimensionless topographic factors of the slope length and the slope steepness, respectively. $\mathrm{C}$ is the dimensionless vegetation cover factor of biological practices for trees, shrubs, and grasslands. $\mathrm{P}$ is the dimensionless factor of engineering practices. $T$ is the dimensionless factor of tillage practices such as crop rotation, contour tillage, residue cover, and intercropping strips [97].

\subsubsection{Integrated Resistance Surface}

The resistance surface parameterization in the present study is generally simplified to set the resistance value according to the land-cover cover type [93]. Nevertheless, this method ignores other perturbing factors on animal movement, such as the influence of topography, road traffic, towns, water pollution, and air pollution [39]. By referring to an ESP study on Jiangxi (central Yangtze river) [42] and Jiangxi (lower Yangtze river) [88], the setting of the resistance surface in this paper is shown in Table 4.

Table 4. Resistance value criteria for different resistance types.

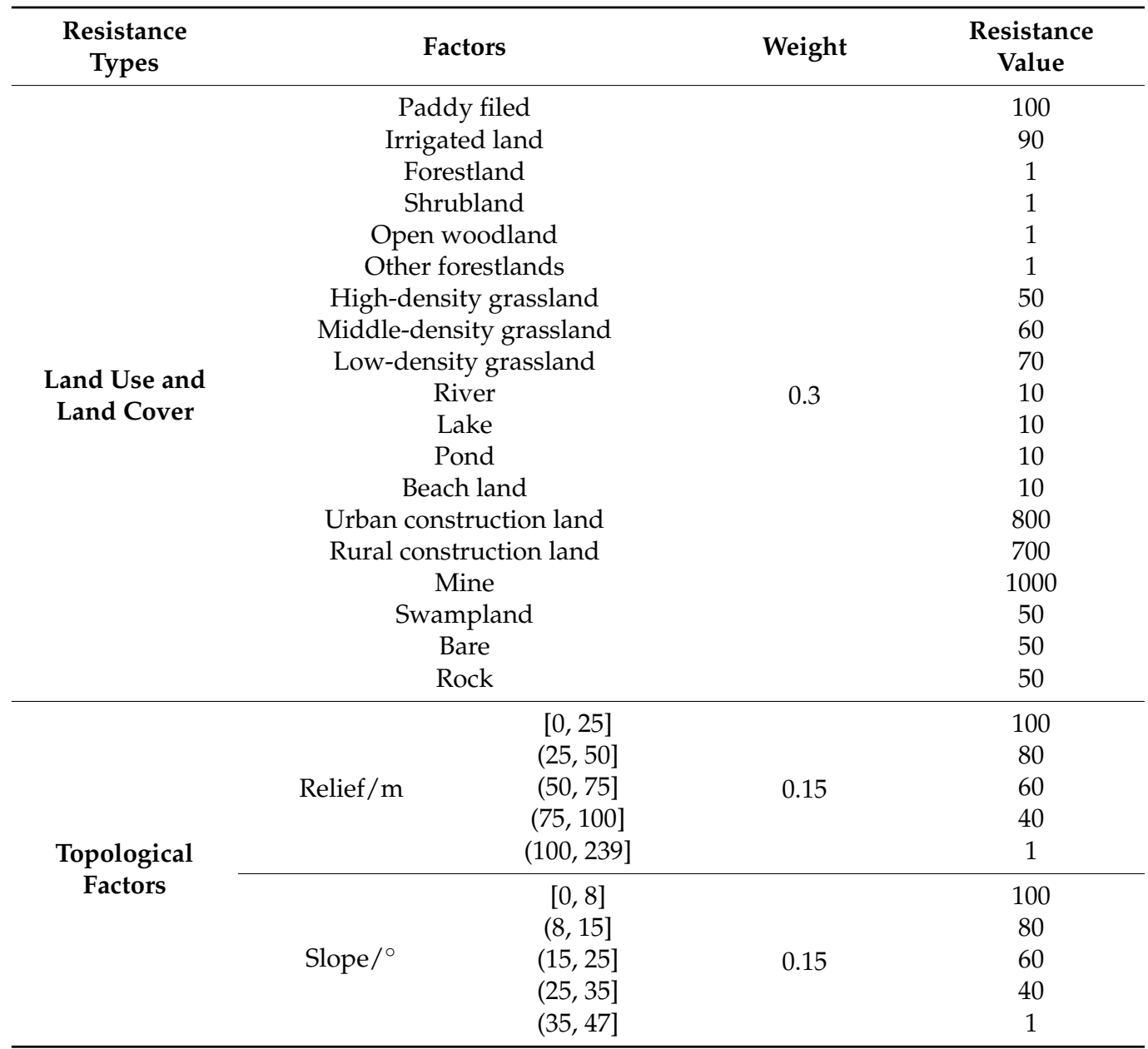


Table 4. Cont.

\begin{tabular}{|c|c|c|c|c|}
\hline $\begin{array}{c}\text { Resistance } \\
\text { Types }\end{array}$ & \multicolumn{2}{|c|}{ Factors } & Weight & $\begin{array}{l}\text { Resistance } \\
\text { Value }\end{array}$ \\
\hline \multirow{12}{*}{ Road } & Distance to road & {$[0,200]$} & \multirow{6}{*}{0.15} & 100 \\
\hline & I (railroad, & $(200,400]$ & & 80 \\
\hline & national & $(400,800]$ & & 60 \\
\hline & highway, & $(800,1600]$ & & 40 \\
\hline & provincial & $(1600,3200]$ & & 20 \\
\hline & highway) & $(3200,+\infty)$ & & 1 \\
\hline & \multirow{6}{*}{$\begin{array}{c}\text { Distance to road } \\
\text { II (country } \\
\text { highway) }\end{array}$} & {$[0,150]$} & \multirow{6}{*}{0.15} & 100 \\
\hline & & $(150,250]$ & & 80 \\
\hline & & $(250,450]$ & & 60 \\
\hline & & $(450,800]$ & & 40 \\
\hline & & $(800,1000]$ & & 20 \\
\hline & & $(1000,+\infty)$ & & 1 \\
\hline \multirow{5}{*}{$\begin{array}{c}\text { Pollution } \\
\text { Sources }\end{array}$} & & {$[0,2000)$} & \multirow{5}{*}{0.1} & 100 \\
\hline & Distance to & {$[2000,4000)$} & & 80 \\
\hline & pollution & {$[6000,8000)$} & & 60 \\
\hline & sources $(\mathrm{m})$ & {$[8000,10,000)$} & & 40 \\
\hline & & {$[10,000,+\infty)$} & & 1 \\
\hline
\end{tabular}

\subsubsection{Extraction of Ecological Corridors}

To find the least-cost corridors between ES patches and the rank of connectivity importance in these corridors, we used linkage pathways to map the least-cost corridors. We used Centrality Mapper to detect the centrality of ES patches and corridors. In the Linkage Pathways tool, each cell in a resistance map is attributed a value reflecting the energetic "cost," (i.e., difficulty and mortality risk) of moving across that cell. As animals move away from specific core areas, cost-weighted distance analyses produce maps of the total cumulative movement resistance. The optimal corridors and potential corridors were derived in this way. In the Centrality Mapper tool, each core area is treated as a node, and each link is assigned a resistance equal to the cost-weighted distance of the corresponding least-cost corridor. The higher the score of the centrality of a path is, the higher the number of ESs it connects. The higher the centrality of the ecological patch is, the higher the number of adjacent ecological patches and corridors it will influence [64]. In addition, we calculated the improvement score and priority score of each ecological corridor. We found the top 40 important barriers and 40 pinch points in the Jianghan Plain to detect the place where ecological resistance needs to be lowered and the most important area in corridors for ecological conservation. More details on circuit theory and Circuitscape software can be found in McRae et al. (2008) [61] and McRae and Shah (2009) [91].

The width of ecological corridors impacts the ecological function of a corridor, and the width of reasonable corridors varies with species, corridor structure, and connectivity. Csuti et al. (1991) claimed that corridor width is important because edge effects penetrate some distance into the corridor. Typically, edge effects can be measured 200-600 $\mathrm{m}$ into a forest from the edge, and corridors narrower than $1200 \mathrm{~m}$ will not contain a true interior habitat [98]. The width for the migration of large mammals should be sev-eral hundred meters or more. Harris (1991) noted that when we take all species into account, the appropriate corridor width should be greater than $915 \mathrm{~m}$ for assemblages of entire species [99]. Based on published research $[100,101]$, we concluded that the dispersal distance of most terrestrial animals and birds on the Jianghan Plain ranges from 3 to $2000 \mathrm{~m}$. Thus, $1 \mathrm{~km}$ should be an appropriate width for most species in the study area. Therefore, the width of ecological corridors in the Jianghan Plain was de-fined as $1 \mathrm{~km}$. Based on this assumption, the minimum search radius of Barrier Mapper was set to $200 \mathrm{~m}$ with the same size as the grid, and the maximum search radius was set to $1000 \mathrm{~m}$. The barrier was searched by the moving window method. 
We used the zonal statistic as a table function of ArcGIS to extract the average improvement scores of each corridor, and the ecological corridors were divided by the quantile method into levels of connectivity enhancement potential, with the highest connectivity enhancement potential being the very high level and the lowest enhancement potential being the low level.

\section{Results}

\subsection{Spatial Pattern of Ecological Services, Ecological Sensitivity, and Ecological Sources}

The spatial patterns of habitat quality, carbon storage, water yield, and integrated ecological services on the Jianghan Plain are shown in Figure 3. The spatial patterns of these ecological services varied, mainly due to different land-cover types and topologies. The high habitat quality area was in the north of Jianghan Plain where Jin Mountain and Dahong Mountain are; this region has wetlands, lakes, and rivers that are high in habitat quality, such as the Han River in the middle of the study area, the Yangtze river in the southeast and Honghu Lake in the southeast. The low habitat quality area was distributed in the center of the study area where there is intensive human activity, less vegetable coverage, and in more built-up areas. The high carbon storage area was in the north and in the western mountainous area where the vegetation density is high, including Jin Mountain, Julong Mountain, and Dahong Mountain. The low carbon storage area was distributed in the center and south of the study area, where intensive built-up areas, rivers, and lakes are located. The place with the highest level of water yield was in the southeastern Jianghan Plain, which is the lowest area of the Jianghan Plain, and many rivers, including the Han River, Yangtze river, and Dafu River, merge in this area. The integrated ecological service map shows the combined characteristics of the above three ecological services on the Jianghan Plain. We divided the results into four levels (non-important, slightly important, moderately important, and extremely important). The land with the highest level of ecological service, covering $3723.95 \mathrm{~km}^{2}$, accounted for $9.08 \%$ of the study area. The land-cover types mainly included forestland, cropland, and water bodies, accounting for $49.00 \%, 25.48 \%$, and $20.83 \%$ of the extremely important area, respectively.

The spatial pattern of ecological sensitivity, including habitat sensitivity, water sensitivity, and soil erosion sensitivity, is shown in Figure 4. Places with high soil erosion were mainly distributed at the foot of mountains or along rivers, especially along the lower ridge of rivers. This result was because the human activity in these places was high and the soil cover $(\mathrm{C})$, conservation practices $(\mathrm{P})$, and tillage operations $(\mathrm{T})$ were lower than those in the mountainous area.

Almost every county had a high level of water sensitivity, except for Zhongxiang city and Jinshan city. These two cities had more forestland and less water area than other cities. The ecological red line area (natural reserves) and main roads had high habitat sensitivity. For example, the Hanjiang wetland nature reserve in Jinmen city and the Changhu wetland nature reserve in Jinmen city are vital for rare animals such as the leopard, forest musk, Oriental white stork, and golden eagle. Suizhou Ginkgo Forest Natural Park is an important habitat for ginkgo. The integrated ecological sensitivity map shows that the central urban area was more vulnerable and influenced by multiple factors, including poor soil protection, radiation of pollution sources, and human activity interference. The three indicators derived the comprehensive ecological sensitivity. The result was divided into four levels (non-sensitive, slightly sensitive, moderately sensitive, and extremely sensitive). Extremely sensitive places were clustered at the edges of cities, where polluted industries were located and where there was a high density of roads. The land with extreme sensitivity covered $3232.90 \mathrm{~km}^{2}$, accounting for $7.83 \%$ of the research area. The land-cover types of the extremely sensitive areas mainly included cropland, builtup area, and water bodies, accounting for $55.11 \%, 19.56 \%$, and $16.31 \%$ of the extremely sensitive area, respectively. 

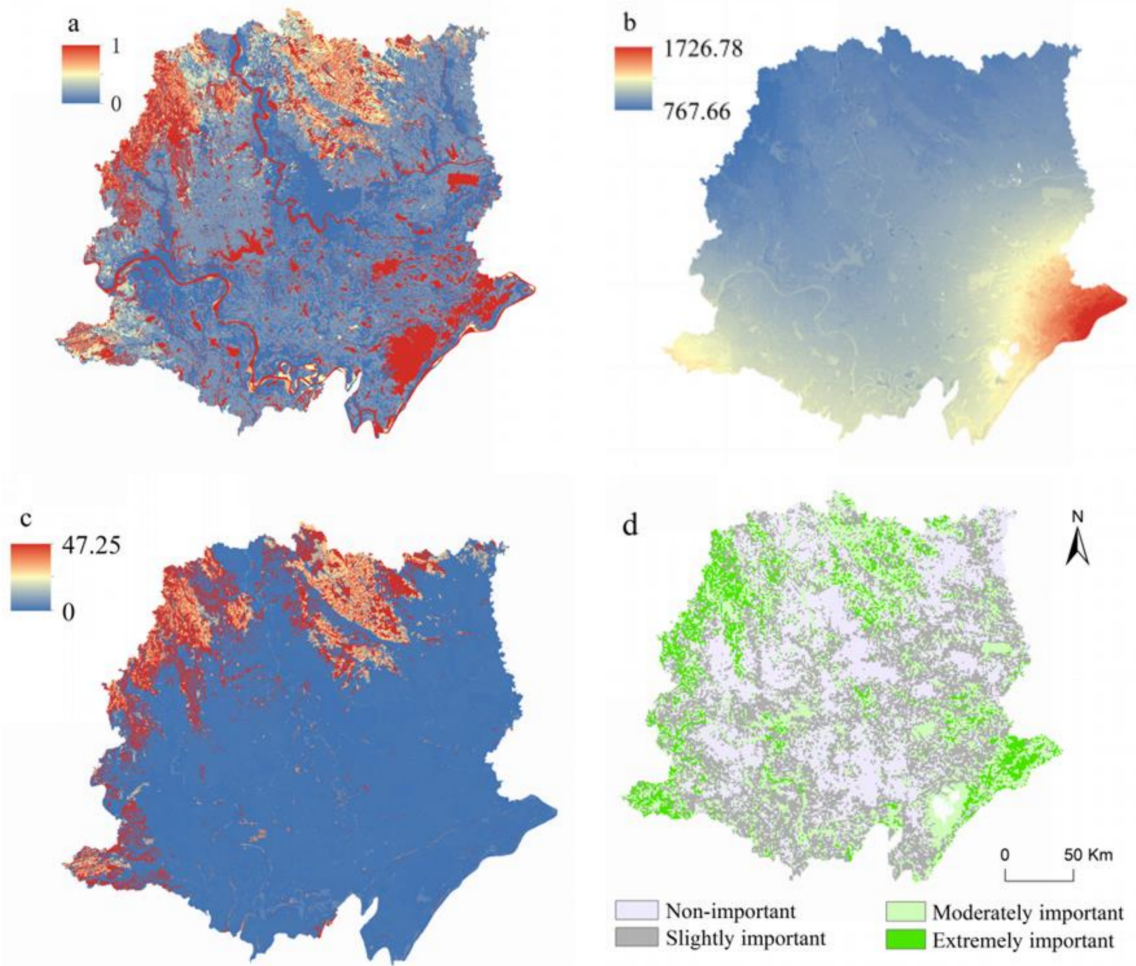

Figure 3. Ecosystem services in the Jianghan Plain. (a) Habitat quality (1 represents the place with the highest habitat quality, 0 reflects the place with the lowest habitat quality); (b) water yield (mm/yr); (c) carbon storage (t.ha $\left.{ }^{-2} \mathrm{yr}^{-1}\right) ;(\mathbf{d})$ integrated ecosystem service).
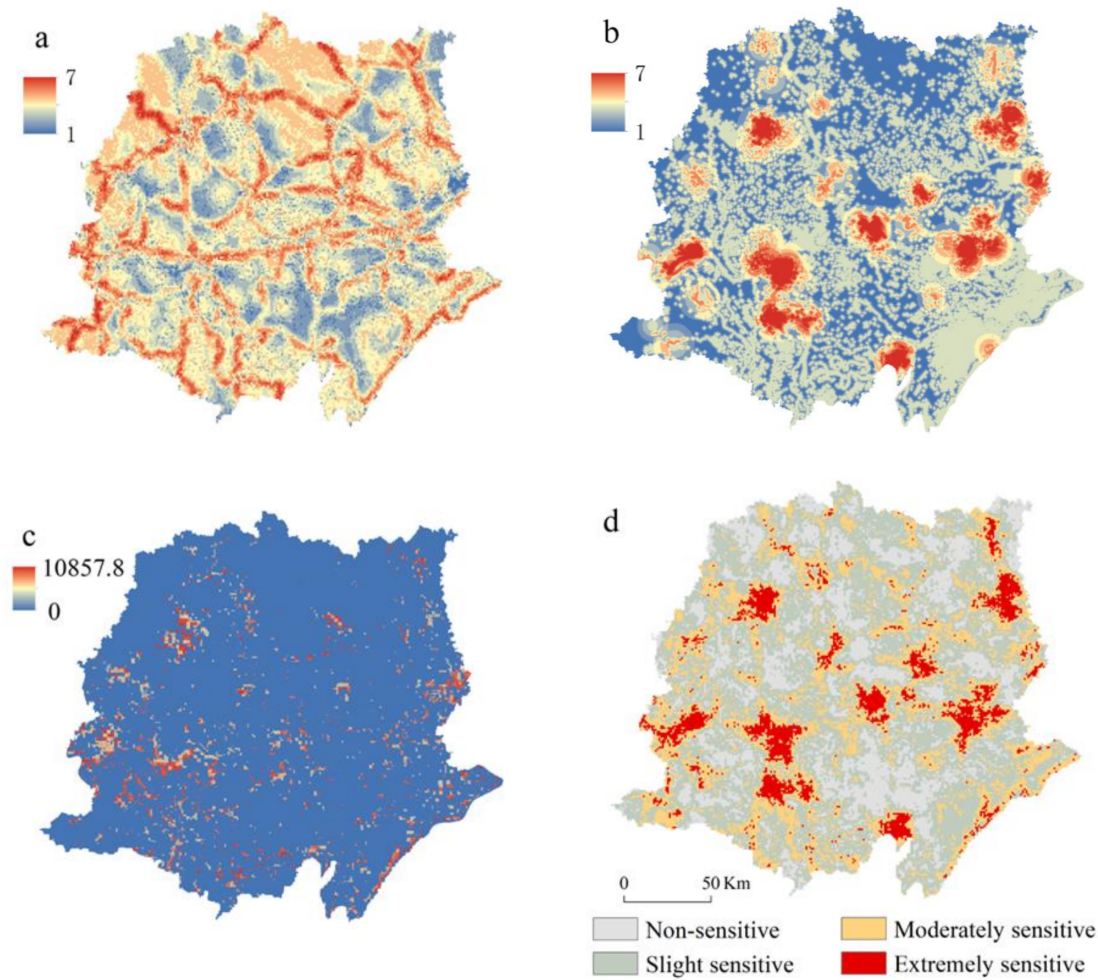

Figure 4. Ecological sensitivity in Jianghan Plain. (a) Habitat sensitivity; (b) water sensitivity; (c) soil erosion sensitivity(t.hm $\left.{ }^{-2}\right)$; (d) integrated ecological sensitivity). 
The areas with higher ecological importance (Figure 5a) were distributed in the north and southeastern Jianghan Plain, mainly located in Zhongxiang city, Dangyang city, Dongbao district, Jinmen city, and Songzi city. The less ecologically important areas were mainly in the urban areas of Tianmen, Xiantao, Qianjiang, and Hanchuan.

In this study, 48 ES lands were identified (Figure $5 b$ ), totaling $3812.95 \mathrm{~km}^{2}$, accounting for $9.12 \%$ of the total area of the study area. The ecological red line area $\left(3082.40 \mathrm{~km}^{2}\right)$ accounted for $80.84 \%$ of the total area of ESs. It mainly consisted of water $\left(1827.12 \mathrm{~km}^{2}\right)$, forestland $\left(1755.36 \mathrm{~km}^{2}\right)$, and arable land $\left(463.68 \mathrm{~km}^{2}\right)$, among which the ecological land area of Honghu city was the largest, amounting to $20.10 \%$ of the total area of ESs. However, the ecological land area of Jiangling County was the smallest, amounting to $0.00058 \%$ of the total ESs. The ESs that were delineated covered spaces including Yuquansi National Forest Nature Park, Zhangjiahu National Wetland Nature Park, Changhu Ecological Reserve, Yangtze river Chinese sturgeon provincial nature reserve, etc.
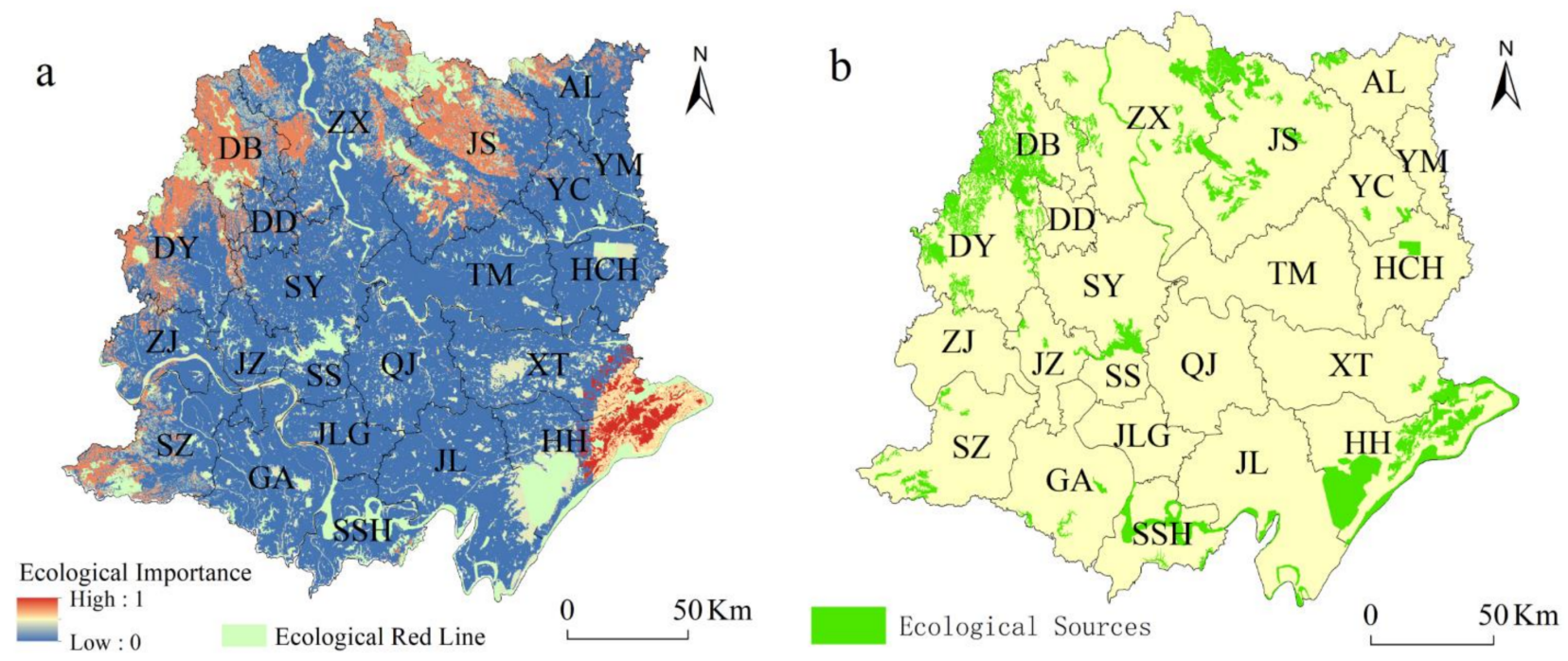

Figure 5. (a) Ecological importance and (b) ecological sources.

\subsection{Integrated Resistance}

The highest resistance value was 441.40 , the minimum resistance value was 1 , and the average resistance value was 65.24 (Figure 6). The spatial variation in the integrated resistance was high. Generally, places that do not have nonpermeable land but have lower relief, lower slopes, lower distances from roads and fewer pollution sources have low resistance. The integrated resistance map showed that the highest resistance area was in the highly popular density area, mainly in the inner cities. Roads, polluted sources, and other interferences were densely concentrated in cities. The cropland around the cities had the second-highest level of resistance. Although cropland has a high level of vegetation coverage, human management makes it suitable only for a specific crop, which hinders the growth of other species. Thus, the resistance value of cropland was relatively high. 
(a) Re1ief (m)

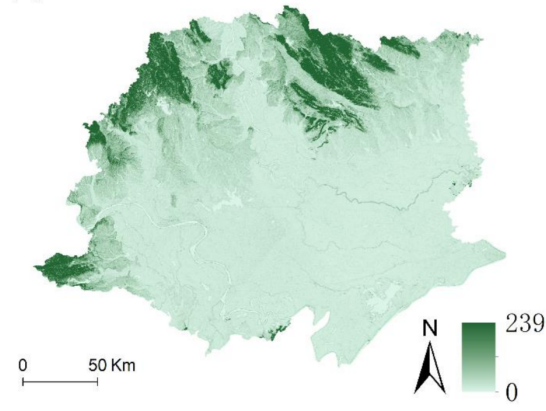

(c) Distance to road I (m)

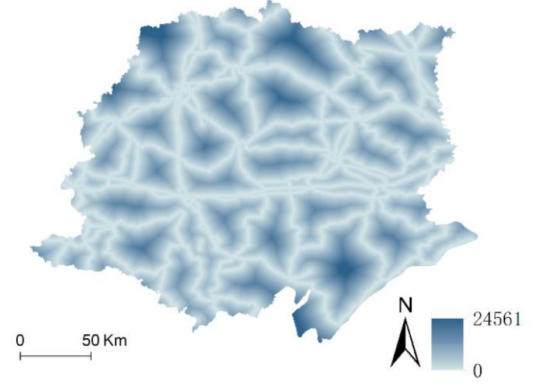

(e) Resistence value under different land use

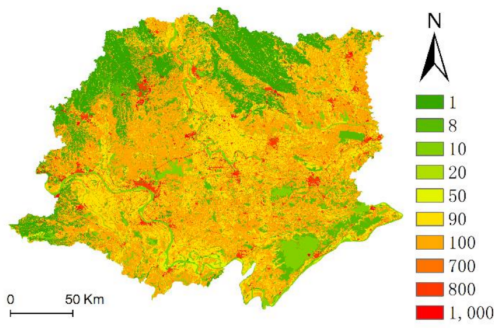

(b) Slope $\left({ }^{\circ}\right)$

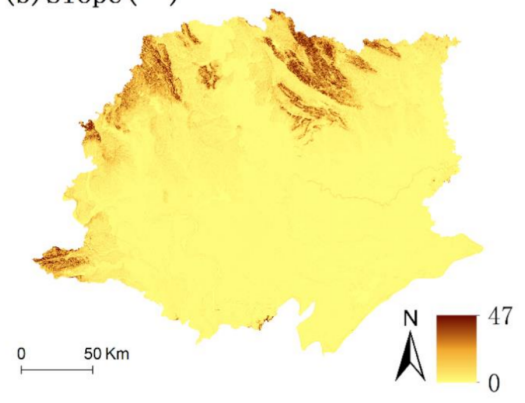

(d) Distance to road II (m)

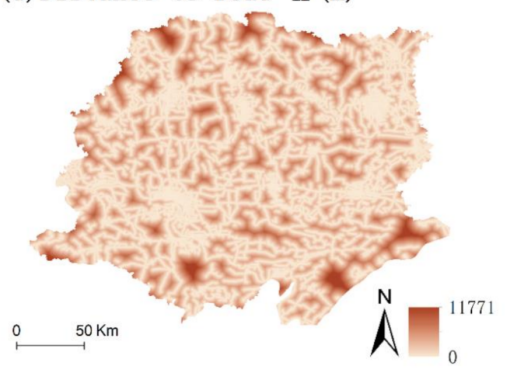

(f)Pollution source

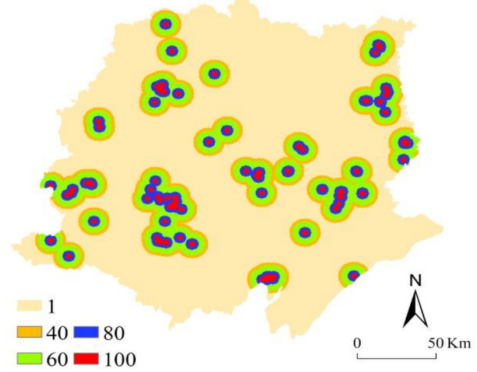

(g) Integrated resistance value

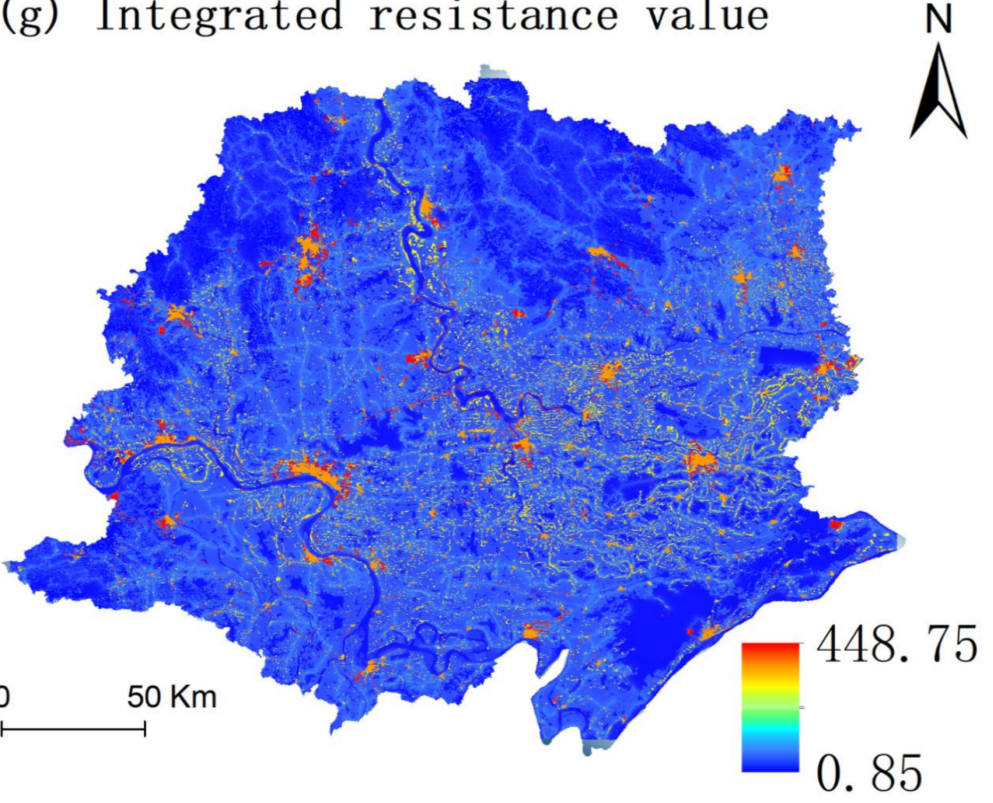

Figure 6. Resistance indicators and integrated resistance surface. (a) Degree of relief; (b) slope; (c) distance from first-class roads; (d) distance from second-class roads; (e) basic resistance of land-cover types; (f) distance to pollution sources; (g) integrated resistance value. 


\subsection{Location of Optimal Ecological Corridors and Potential Corridors}

As shown in Figure 7, 91 optimal ecological corridors were derived, and they had a total length of $2036.28 \mathrm{~km}$. A total of 51 potential corridors were derived, with a total length of $3172.48 \mathrm{~km}$, of which $42.26 \%$ of the potential corridors overlapped with the optimal corridors. Within these optimal corridors, 38 ecological corridors were less than $10 \mathrm{~km}$ in length. The total length of these 38 corridors was $138.90 \mathrm{~km}$, accounting for $6.82 \%$ of the total length of the optimal ecological corridors. The shortest corridor was $0.2 \mathrm{~km}$. The corridors that were shorter than $30 \mathrm{~km}$, accounting for $74.73 \%$ of the total ecological corridors, were clustered in the northwest, southeast, and north of the study area.

The ESs in the central Jianghan Plain were the hubs in ecological migration in the northwest and southeast, and the corridors from the central to the southeast areas were longer, with most main connecting corridors having lengths longer than $50 \mathrm{~km}$. Thus, the overall spatial characteristics of ecological corridors showed a northwest and southeast direction. The ESs in the north and south of the Jianghan Plain were more complex, with gradually increasing connectivity, forming an EN pattern composed of ESs and corridors.

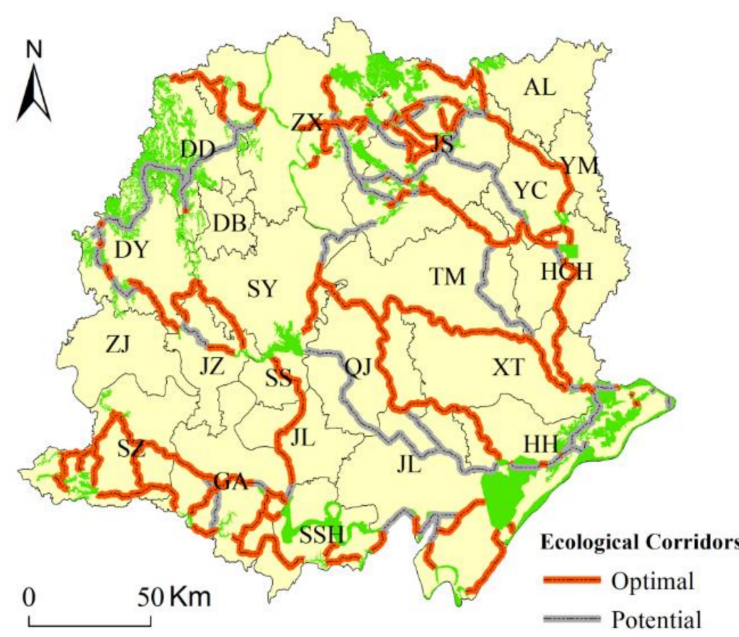

(a)

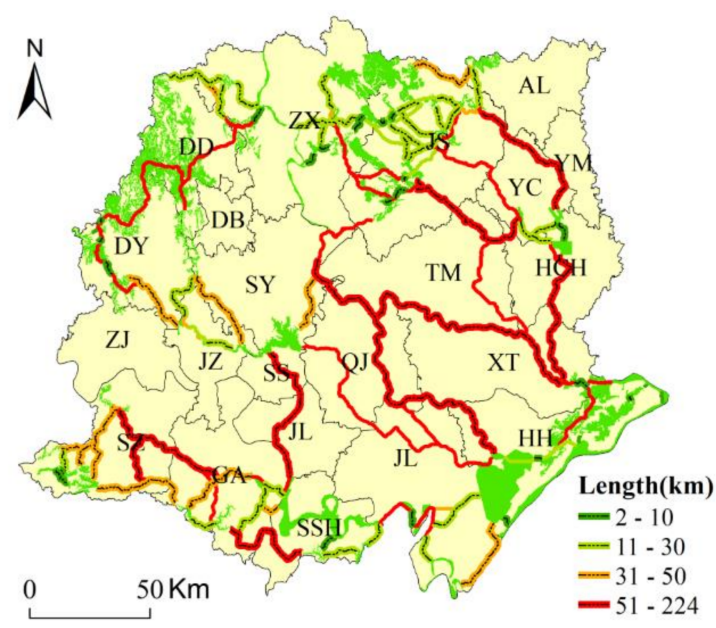

(b)

Figure 7. (a) Location of optimal ecological corridors and potential corridors and (b)length of ecological corridors.

\subsection{Centrality of Ecological Corridors and Sources}

Current flow centrality indicates how important a corridor or ecological area is for keeping the overall EN connected. The more ESs an ecological corridor/ES connects, the higher centrality it has. Ecological sources with high connectivity were mainly located in the Honghu National Nature Reserve and the Hubei Yangtze river Xinluo Baiji National Nature Reserve in Honghu city $(\mathrm{HH})$, the Hubei Yangtze river Swanzhou Baiji Dolphin National Nature Reserve in Shishou city (SSH), the Dagou Forest Park and Geopark in Zhongxiang city $(\mathrm{ZX})$, the Tiger Claw Mountain Forest Park and the Green Forest Park in Jingshan city (JS), and the Zhanghe National Wetland Nature Park and Xianju River National Wetland Nature Park in Jingzhou (JZ). The ecological corridors with high connectivity mainly connected the ESs from the Han River in Shayang County (SY) to Honghu City (HH), the Shahu Wetland from the Han River to Xiantao city (XT), the Tiger Claw Mountain Forest Park in Jingshan city (JS) to the Lao Guanghu National Wetland Natural Park in Xiaogan (XG), and the ESs from the National Wetland Park in Hanchuan $(\mathrm{HCH})$ to the northern part of Honghu City (HH) (Figure 8). 


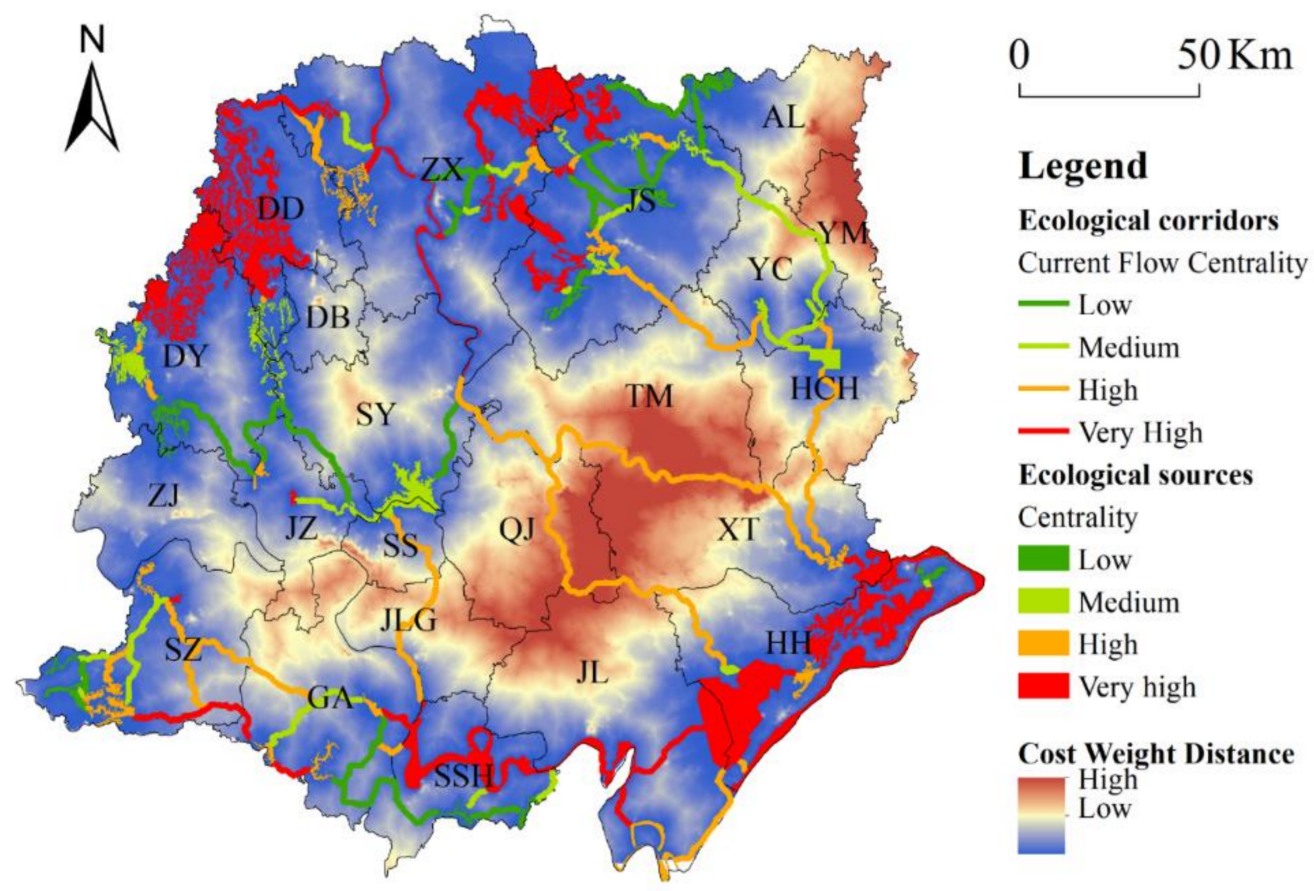

Figure 8. The centrality of habitat corridors and ecological sources.

\subsection{Locations of Barriers and Priority Area}

The overall landscape connectivity of the Jianghan Plain region still has more room for improvement, with points of high improvement scores (ISs) for each corridor. By overlaying each obstacle point with the land-cover map, the land types were identified, and the obstacle point land was mainly urban construction building land (15 barriers), industrial and mining land (18 barriers), and arable land (5 barriers) (Figure 9). Due to the gradual shrinkage and narrowing of the lake and river and the problem of pollution, forest resources are decreasing and fragmentation is gradually increasing; these conditions put pressure on the ecological environment and decrease the connectivity between habitats. These conditions change the original flow direction and flow speed of water bodies, thus hindering the migration path of aquatic and terrestrial organisms in the development process to a certain extent and having a negative impact on the vegetation in the region and the formation on both sides of the road. The use of modern agricultural technology has gradually changed the rice crop from mixed to monoculture planting, the current planting rate in the Jianghan Plain has reached 30\%, and some of the mechanized planting areas may destroy the habitat connectivity because human activities in such areas tend to be more intensive; additionally, the spatial distribution was mostly located at the connection of ESs and ecological corridors, which was a key location for connectivity, especially in JS, $\mathrm{YC}, \mathrm{HCH}, \mathrm{ZX}, \mathrm{XT}$ and other counties.

Pinch points are places where the loss of a small area could disproportionately compromise connectivity. The places that have a higher influence on corridor connectivity would obtain a higher priority score. The pinch points should be protected as priority areas (Figure 10). 
a

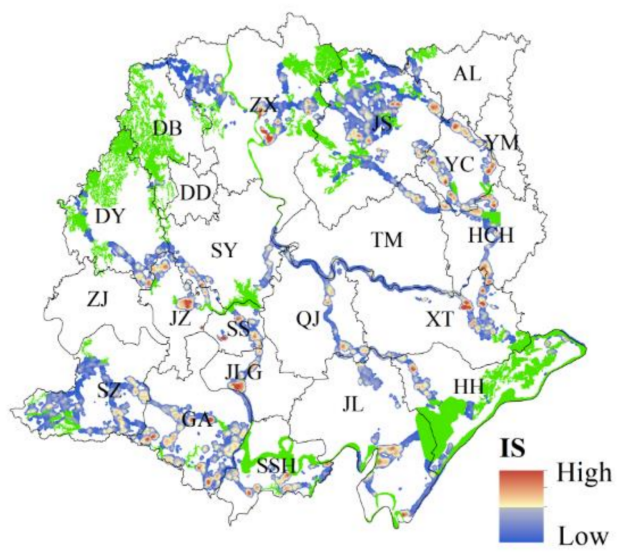

b

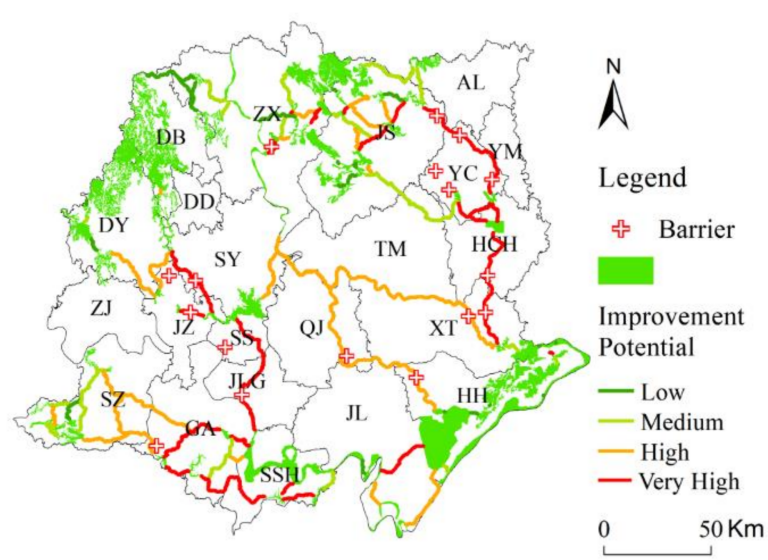

Figure 9. (a)Improvement scores (ISs) and barriers of ecological corridors in the Jianghan Plain and (b)the improvement potential level of each corridor.

In this study, a total of 40 pinch points were identified, whose land-cover types were mainly forestland, water area, and farmland, of which 27 were water areas, 5 were forestland, 8 were farmland, and XT had the most, with 9 pinch points, of which 2 pinch points were farmland, and 7 were water areas. The next highest number was in $\mathrm{HCH}$, with 7 pinch points, of which 2 were cultivated and 7 were water areas; these 40 pinch points were mainly distributed along the corridors in the central part of the Jianghan Plain, with some pinch points in the ecological corridors in the northeastern part of the Jianghan Plain. The ecological corridors connecting the center to the southern part of the Jianghan Plain have a high priority for protection, and they are mostly oriented from northwest to southeast.

a

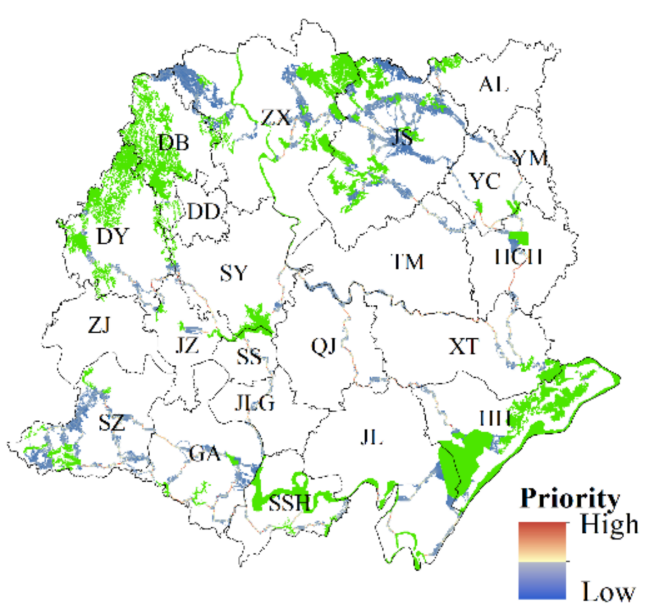

b

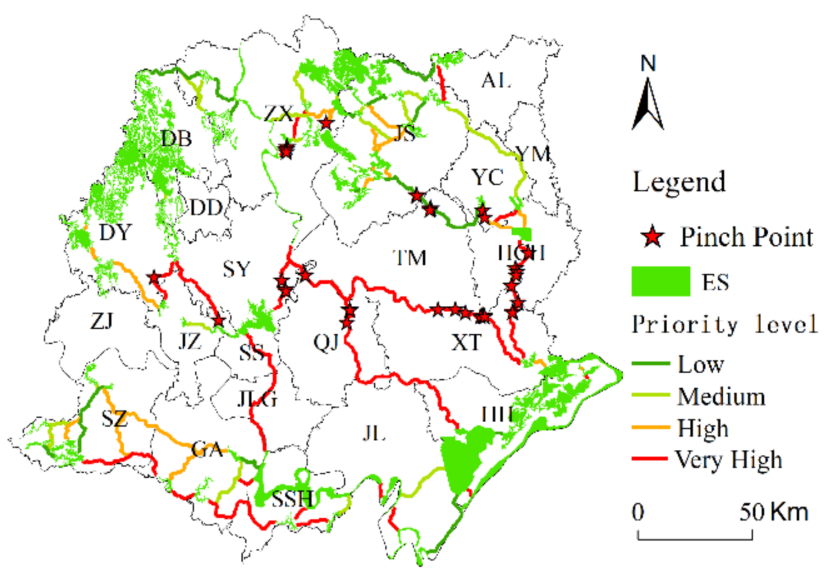

Figure 10. (a) Priority and (b) pinch points of ecological corridors on the Jianghan Plain.

We overlaid the improvement potential level map and priority level map to create a composite map identifying the corridors with the most potential for improvement and the most conservation value (Figure 11). The result showed a total of 11 corridors with a very high level of improvement potential and priority. With the potential for connectivity enhancement, these important corridors mainly connect the central and southern ESs of the Jianghan Plain. The connected ecological reserves were as follows: Pengchang Heron Lake Wetland in Shayang (SY), Hubei Jingzhou Changhu National Wetland in Jinzhou (JZ), Mochou Lake, Hanjiang Soil and Water Conservation Ecological Protection Red Line in Zhongxiang (ZX), Hubei Jingzhou Changhu National Wetland in Shashi (SS), East and West Cha Lake in Yingcheng (YC), Hanbei River Wahoo National Aquatic Germplasm Resource 
Reserve in Yingcheng (YC), Hanbei River Wa's Pelteobagrus fulvidraco National Aquatic Germplasm Resource Reserve in Hanchuan (HCH), Hanchuan Lake National Wetland Park, Hubei Yangtze river Swanzhou Baiji Dolphin National Nature Reserve in Shishou (SSH), Silt Lake, Niu Lang Lake, Huangtian Lake in Gongan (GA), Hubei Yangtze river Swanzhou Baiji Dolphin National Nature Reserve in Gongan (GA), Zhongdock Water Treatment Plant Water Containment Ecological Protection Red Line in Gongan (GA), Shangjin Lake National Aquatic Germplasm Resource Reserve in Shishou (SSH), Xiaogan Lao Guanghu National Wetland Nature Park in Yingcheng (YC).

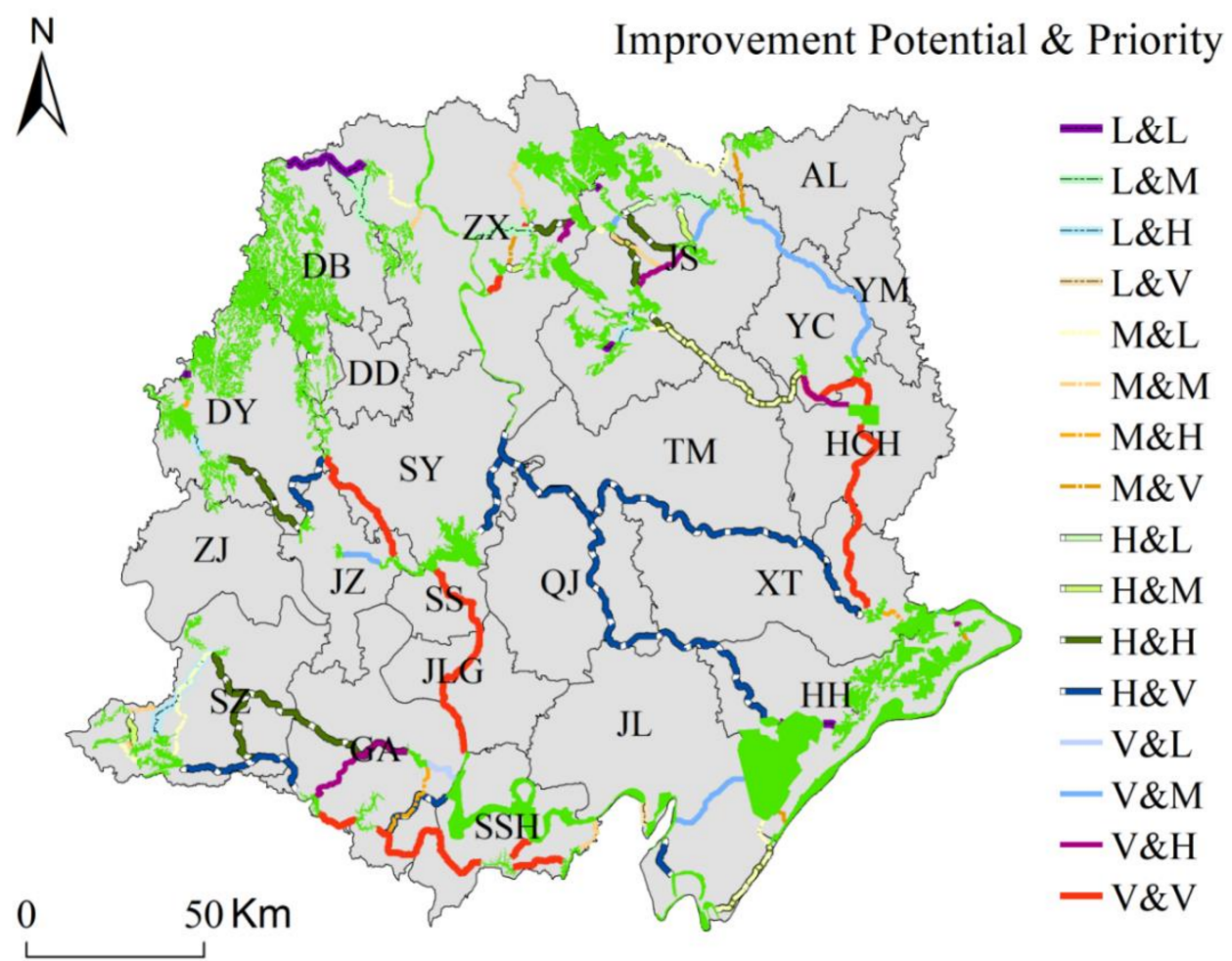

Figure 11. Composite map for improvement potential level and priority; L means low level; M means medium level; $\mathrm{H}$ means high level; $\mathrm{V}$ means very high level; L\&L means the improvement potential level of the corridor is at low level and, at the same time, the priority level of this corridor is at a low level.

\section{Discussion}

\subsection{Discussion on ESP Construction}

Jianghan Plain is located in a subtropical monsoon region, a highly populated area for both urban and agriculture development in central China. In terms of the problem-driven segment, considering the special ecological issues and geospatial differences of Jianghan, we selected a number of key metrics accordingly. For instance, the evaluation of biodiversity, water yield, and carbon storage were particularly meaningful for depicting the vital ecological space in Jianghan Plain, because of the severe biodiversity loss and documented water pollution under climate change and fast industrialization. In addition, we combined ecosystem service indicators and ecological sensitivity indicators when identifying the ecological sources. This ecological source selection framework is corresponding to the national standard of territorial spatial planning - to find the conservation places that are ecologically important, ecologically sensible, and ecologically fragile. We constructed a set of index systems in line with the regional characteristics. The construction of ecological resistance surface in the Jianghan Plain could be applied to similar areas that also have a monsoon climate background and the high-intensity human activity interference. Previous studies [93] only uniformly assign values to land-use types to determine the basic resistance 
surface, which is easy and low cost. However, this method is inaccurate because they did not comprehensively consider the unique geographical characteristic, such as the impact of topological factors and other invisible environmental factors, such as the influence of gas pollution or wastewater on the environment. This paper sets a peculiar ecological environment condition of the Jianghan Plain area and combines elevation, slope, land cover type, topological factors, distance to roads, distance to pollution sources to construct the basic resistance surface and offers a reference for choosing the resistance factor of the populated area.

Unlike using only the minimum cumulative resistance model and land use cover data when constructing ecological corridors that many ESP studies have completed, our study integrated transdisciplinary knowledge (circuit theory from physics, least-cost path analyses from GIS, and landscape ecology from ecology and geography), methodology, and multisource data to construct a holistic framework for designing ESP patterns. Moreover, another novelty of the framework lies in that we extracted the important ecological corridors, classified them according to their centrality, connectivity improvement potential, and priority (importance) and identified 40 sites with the highest improvement potential and highest protection needs. This meets the realistic needs of China's territorial spatial planning and enables the use of feasible methods and available information to find sites for ecological conservation and ecological restoration. The interdisciplinary knowledge of landscape management and integrated methods, such as assessment of ecosystem services and ecological sensitivity, the least-cost path, circuit theory, and the centrality index, were used to construct ESPs and foster harmony between humanity and nature. Due to the great complexity that is conditioned by heterogeneous ecological and geographical contexts, no standard method has yet been reached.

Considering the different topography and regional economic development status of different regions, the demand for ecological services and ecological damage are different, which influence the selection of indicators for ecological quality evaluation, ecological sensibility evaluation, and resistance factors. For example, in the Karst area, to construct the basic resistance surface, researchers need to consider the mechanism for the rock desertification formation. When choosing indicators for constructing resistance surface, researcher could combine the regular indicators such as elevation, slope, land cover type, vegetation coverage, and particular indicators that could illustrate the Karst geography, such as lithology and soil thickness [102]. The logical framework of this research is in line with national needs, while the selection of indicators is not universal. Although an accurate evaluation of corridor efficiency remains challenging, the restoration measures targeting priority corridors are far more effective than those implemented in a random fashion. This article can serve as a reference for setting parameters and research frameworks for ecological security patterns in subtropical monsoonal and densely populated areas.

\subsection{Discussion on Robustness of the Results}

We demonstrated the robustness of the results from three aspects. First, the National Ecological Protection Red Line of Hubei Province was positioned within the ES patches that we identified. As China's ecological protection red line delineates land where land-cover changes are not allowed, which involves a conflict of interest between ecological protection and local economic development, the area of the ecological protection red line delineated by the Department of Natural Resources of Hubei Province is relatively smaller than that of the land identified by the integrated approach in this study. Second, the wetlands surrounding lakes and rivers in the southern region and in the hills of the northwestern region are abundant with protected wildlife species [16], and the central Jianghan Plain, which occupies mostly cropland and built-up areas, has less protected wildlife. Third, to verify the feasibility of protecting the corridors, we analyzed the ecological land proportion by overlapping the land-cover map with corridors with a $1 \mathrm{~km}$ width. The results showed that $46.61 \%$ of corridors were cropland, $26.86 \%$ were woodland, and $20.12 \%$ were water bodies, which indicated that protecting the selected corridors in the real world is feasible. 
The land structure of each ecological corridor is presented in Appendix A (Figure A1). The information about the top 40 pinch points and top 40 barriers is presented in Appendix A (Figure A2, Table A2 \& Table A3).

\subsection{Discussion on Weakness of this Research}

This research has two weaknesses that remain to be improved. First, the evaluation methods of ecological quality and ecological sensitivity in our research are commonly used by ecological evaluation studies on large scales. However, the quality of ecological evaluation methods and results could be further enhanced if we had more field data. For example, if we had water quality sample data, we would know the overall spatial pattern of water quality in the study area through remote sensing inversion. By doing so, we could distinguish the habitat quality and resistance values of the water area. Thus, improving assessment quality requires the improvement of evaluation methods and an increase in field data. Second, the parameterization (e.g., resistance value for land-cover types, the size of ESs, search radius for barrier analysis) was based on subjective determinates by referring to similar studies in Central China, which may introduce bias in the analysis results. With the diversification and enrichment of geographic data, these problems will be solved.

\section{Conclusions}

In the context of rapid urbanization, human beings are using land intensively, which will affect the sustainability of human society and jeopardize the quality of human life in the long run. Therefore, it is urgent to understand the current spatial distribution of ecological services and ecological sensitivity to construct EN patterns. We constructed an EN pattern in the Jianghan Plain and prioritized corridors by developing an integrated framework. Our results identified 48 ESs and 91 corridors on the Jianghan Plain. ESs were mainly distributed in the water area and wetlands in the north and southeastern Jianghan Plain, mainly located in Zhongxiang city, Dangyang city, Dongbao District of Jinmen Honghu Shishou city, and Songzi city. Ecological corridors could be divided into three sets based on their spatial pattern: one set of corridors was connected the ESs from central or north to south, one set connected the ES sites that were relatively parallel to latitudes in the north of the study area, and another set of ecological corridors were parallel to latitudes in the south. There were 11 priority corridors with a very high level of connectivity improvement potential and a very high level of conservation priority, occupying $16.15 \%$ of the total length. The corridors with high connectivity improvement potential and high priority were mainly located in the central and southern parts of the Jianghan Plain. These corridors should be well protected and restored.

This study identified corridor barriers and priorities by combining circuit theory with GIS spatial analyses, showed the spatial heterogeneity of ecological corridors, and identified the nodes needing further restoration and conservation. This study provides an efficient way to help local decision-makers in natural connectivity planning.

Author Contributions: X.S. designed this study and formed the raw manuscript; Q.L. did the modelling, data analysis and formed the revised manuscript; Y.Z. funded this study and revised the final version of manuscript; All the authors are involved in manuscript writing. All authors have read and agreed to the published version of the manuscript.

Funding: This work was supported by The National Natural Science Foundation of China (41271534); China Scholarship Council (201906770044).

Institutional Review Board Statement: Not applicable.

Informed Consent Statement: Not applicable.

Data Availability Statement: Not applicable.

Acknowledgments: Thank Xiaoman Xu from Wuhan University for facilitating data. Thank Shuangquan Chen and Yong Fan for Visualization. We acknowledge all people who contributed to the data 
collection and processing, as well as the constructive and insightful comments by the editor and anonymous reviewers.

Conflicts of Interest: The authors declare no conflict of interest.

\section{Appendix A}

Table A1. The explanation of the evaluation models and model parameters.

\begin{tabular}{|c|c|c|c|c|}
\hline $\begin{array}{l}\text { Evaluation } \\
\text { Indicators }\end{array}$ & Evaluation Model & Model Parameters & Parameters Sources & Reference \\
\hline \multirow{4}{*}{ Habitat Quality } & \multirow{4}{*}{$\begin{array}{l}\text { Habitat Quality } \\
\text { module in InVEST } \\
\text { model }\end{array}$} & $\begin{array}{l}\text { Distance between the } \\
\text { habitat and threat sources }\end{array}$ & $\begin{array}{l}\text { Calculated using Land } \\
\text { use/cover map }\end{array}$ & \multirow{4}{*}{ Li et al. (2021) [83] } \\
\hline & & Level of legal in each cell & Default value & \\
\hline & & $\begin{array}{c}\text { Relative impact of each } \\
\text { threat }\end{array}$ & \multirow{3}{*}{$\begin{array}{l}\text { Assignment values } \\
\text { according to previous } \\
\text { studies }\end{array}$} & \\
\hline & & $\begin{array}{l}\text { Relative sensitivity of each } \\
\text { habitat type to threat }\end{array}$ & & \\
\hline \multirow{2}{*}{ Carbon Storage } & \multirow{2}{*}{$\begin{array}{l}\text { Carbon storage and } \\
\text { sequestration module } \\
\text { in InVEST model }\end{array}$} & Carbon pools & & \multirow{2}{*}{$\begin{array}{c}\text { Tang et al. (2020) } \\
\text { [103] }\end{array}$} \\
\hline & & Land use/cover & \multirow{2}{*}{$\begin{array}{l}\text { Derived from Land } \\
\text { use/cover map }\end{array}$} & \\
\hline \multirow{7}{*}{ Water Yield } & \multirow{7}{*}{$\begin{array}{l}\text { Water yield module in } \\
\text { InVEST model }\end{array}$} & Land use/cover & & \multirow{7}{*}{$\begin{array}{l}\text { Yang et al. (2019) } \\
\text { [92] }\end{array}$} \\
\hline & & Precipitation & Calculated using & \\
\hline & & $\begin{array}{l}\text { Average annual reference } \\
\text { evapotranspiration }\end{array}$ & Meteorological data & \\
\hline & & Root restricting layer depth & & \\
\hline & & $\begin{array}{c}\text { Plant available water } \\
\text { content }\end{array}$ & Calculated using Soil data & \\
\hline & & $\mathrm{Z}$ parameter & $\begin{array}{l}\text { Assignment values } \\
\text { according to previous } \\
\text { studies }\end{array}$ & \\
\hline & & $\begin{array}{l}\text { Watersheds/sub } \\
\text { watersheds }\end{array}$ & \multirow{2}{*}{ Calculated using DEM } & \\
\hline \multirow{4}{*}{$\begin{array}{l}\text { Soil Erosion } \\
\text { Sensitivity }\end{array}$} & \multirow{4}{*}{ CSLE model } & $\begin{array}{c}\text { Slope length L/slope } \\
\text { steepness S }\end{array}$ & & \multirow{4}{*}{$\begin{array}{l}\text { Liu et al. }(2020) ; \\
\text { Gao et al. }(2021) \\
\quad[97,104]\end{array}$} \\
\hline & & Rainfall erosivity $\mathrm{R}$ & $\begin{array}{l}\text { Calculated using } \\
\text { Meteorological Data }\end{array}$ & \\
\hline & & Soil erodibility K & Calculated using Soil data & \\
\hline & & $\begin{array}{l}\text { Cover management } \\
\text { C/engineering practices } \\
\mathrm{P} / \text { tillage practices } \mathrm{T}\end{array}$ & $\begin{array}{l}\text { Assignment values } \\
\text { according to previous } \\
\text { studies }\end{array}$ & \\
\hline \multirow{3}{*}{ Water Sensitivity } & $\begin{array}{l}\text { The distance to water } \\
\text { body }\end{array}$ & $\begin{array}{l}\text { Classification of distance to } \\
\text { water body }\end{array}$ & $\begin{array}{l}\text { Calculated using land-use } \\
\text { and land cover map }\end{array}$ & \multirow{3}{*}{$\begin{array}{c}\text { Yimin et al. (2018); } \\
\text { Xiao et al. (2020) } \\
{[93,94]}\end{array}$} \\
\hline & $\begin{array}{l}\text { Distance to wastewater } \\
\text { sources or sewage } \\
\text { treatment plant }(\mathrm{m})\end{array}$ & $\begin{array}{l}\text { Classification of distance to } \\
\text { wastewater sources or } \\
\text { sewage treatment plant }\end{array}$ & $\begin{array}{c}\text { Calculated using } \\
\text { wastewater sources map } \\
\text { and sewage treatment } \\
\text { plant distribution map }\end{array}$ & \\
\hline & $\begin{array}{l}\text { Distance to polluting } \\
\text { air sources }(\mathrm{m})\end{array}$ & $\begin{array}{l}\text { Classification of distance to } \\
\text { polluting air sources }\end{array}$ & $\begin{array}{c}\text { Calculated using polluting } \\
\text { air sources map }\end{array}$ & \\
\hline
\end{tabular}


Table A1. Cont.

\begin{tabular}{|c|c|c|c|c|}
\hline $\begin{array}{l}\text { Evaluation } \\
\text { Indicators }\end{array}$ & Evaluation Model & Model Parameters & Parameters Sources & Reference \\
\hline \multirow{4}{*}{ Habitat Sensitivity } & $\begin{array}{l}\text { The distance to major } \\
\text { roads }\end{array}$ & $\begin{array}{c}\text { Classification of distance to } \\
\text { major roads }\end{array}$ & $\begin{array}{l}\text { Calculated using } \\
\text { transportation planning } \\
\text { map }\end{array}$ & \multirow{4}{*}{$\begin{array}{c}\text { Rayfield et al. } \\
\text { (2010); Yimin et al. } \\
(2018)[94,105]\end{array}$} \\
\hline & $\begin{array}{c}\text { The distance to nature } \\
\text { reserves }\end{array}$ & $\begin{array}{c}\text { Classification of distance to } \\
\text { nature reserves }\end{array}$ & $\begin{array}{l}\text { Calculated using nature } \\
\text { reserve distribution map }\end{array}$ & \\
\hline & Land use types & $\begin{array}{l}\text { Classification of Land use } \\
\text { types }\end{array}$ & $\begin{array}{l}\text { Reclassified using land } \\
\text { use/cover map }\end{array}$ & \\
\hline & NDVI & $\begin{array}{l}\text { Classification of NDVI } \\
\text { value }\end{array}$ & Reclassified using NDVI & \\
\hline
\end{tabular}

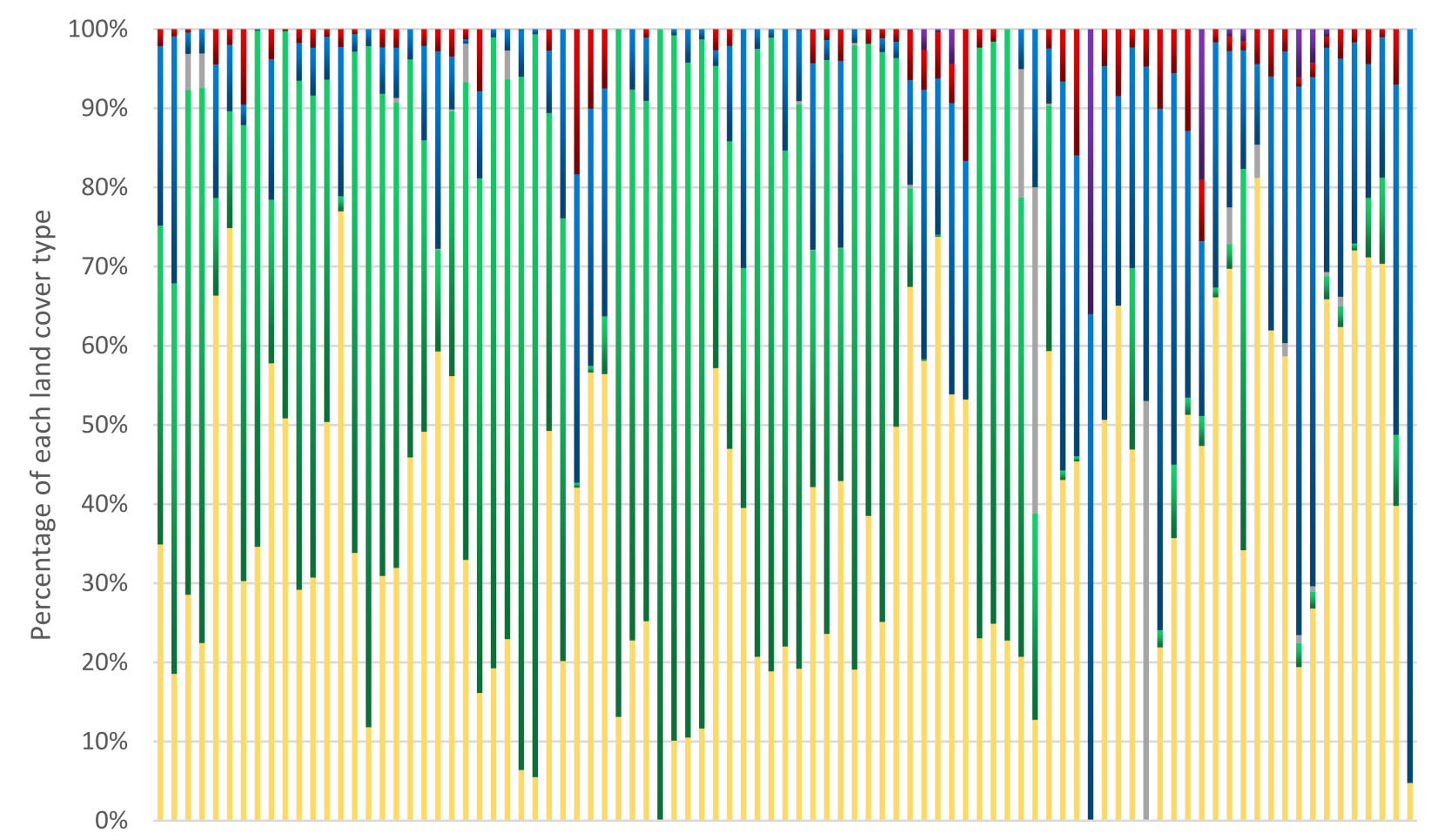

135791113151719212325272931333537394143454749515355575961636567697173757779818385878991 Corridor ID

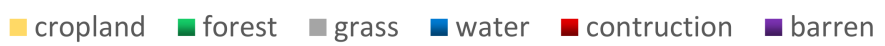

Figure A1. Land use structure of the ecological corridors. 

$111^{\circ} 0^{\prime} 0 " \mathrm{E}$
$112^{\circ} 0^{\prime} 0^{\prime \prime} \mathrm{E}$
$113^{\circ} 0^{\prime} 0 " \mathrm{E}$
$114^{\circ} 0^{\prime} 0 " \mathrm{E}$
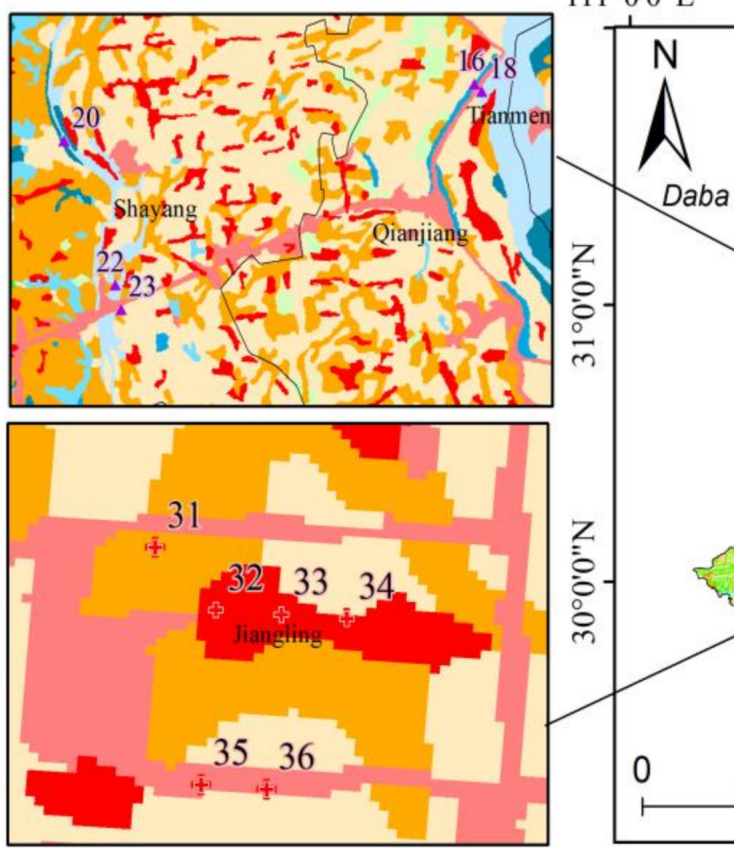

Daba mountain

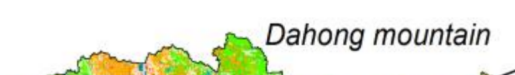

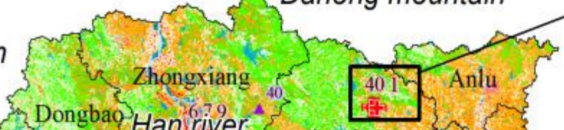

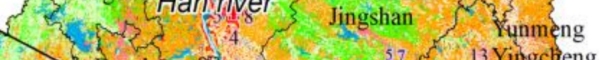
Dangyang (19) Shavan 20 .

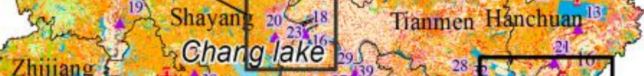
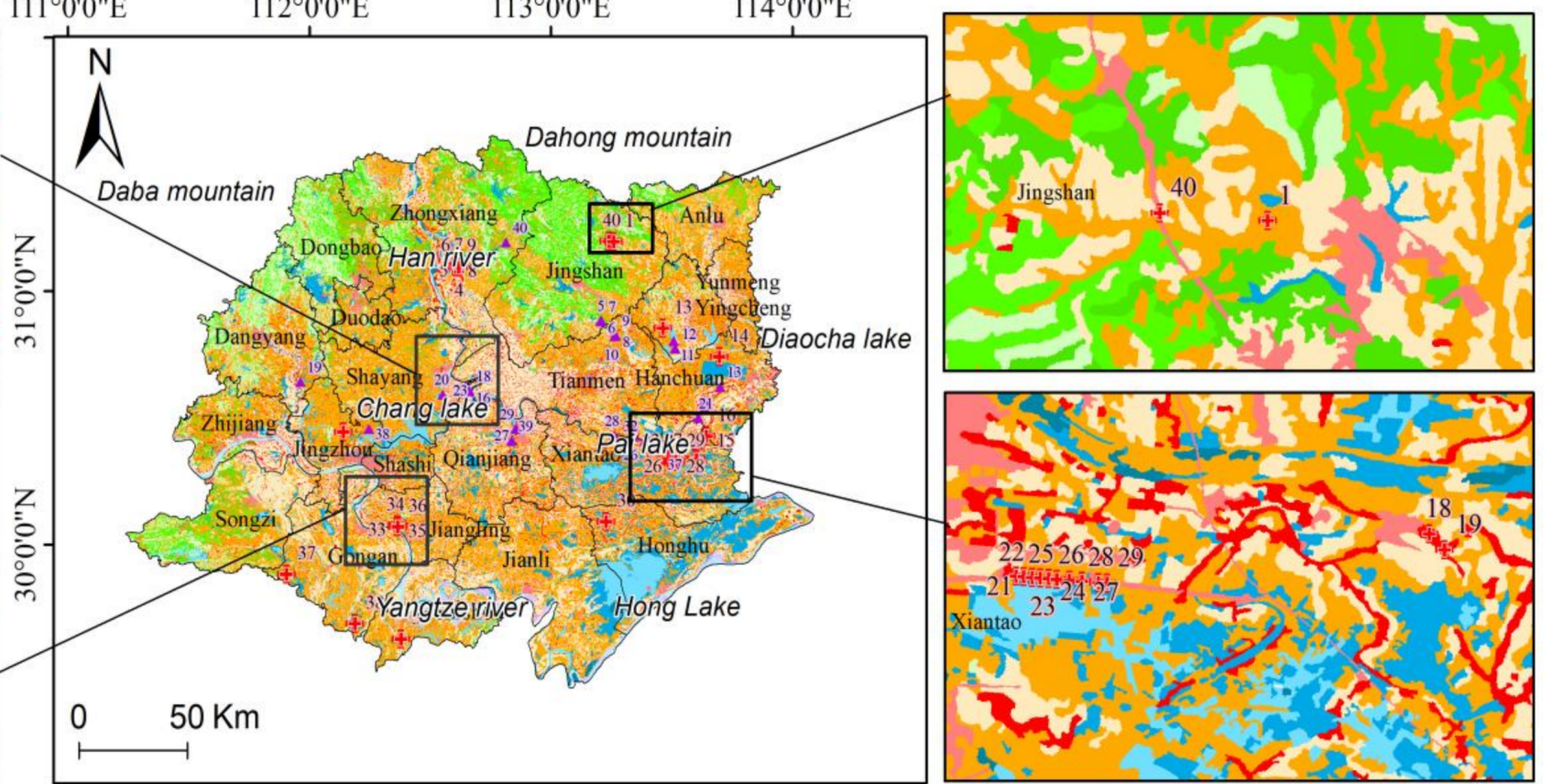

Legend

$\square$ Paddy filed $\square$ Open woodland

^ Pinch Point

$\square$ Irrigated land $\square$ Other forestlands

$\square$ Middle-density grassland

Beach land

¿' Barrier

$\square$ Forestland $\square$ High-density grassland

$\square$ River $\square$ Swampland

$\square$ Urban construction land

$\square$ County Boundary $\square$ Shrubland

$\square$ Lake

Bare

- Rural construction land

Figure A2. Top 40 pinch points and top 40 barriers in Jianghan Pl. 
Table A2. Information about top 40 pinch points.

\begin{tabular}{|c|c|c|c|c|}
\hline Rank & Land Cover Type & Latitude & Longitude & County \\
\hline 1 & Lake & 112.63 & 31.11 & Zhongxiang \\
\hline 2 & Lake & 112.62 & 31.10 & Zhongxiang \\
\hline 3 & Paddy filed & 112.62 & 31.10 & Zhongxiang \\
\hline 4 & Paddy filed & 112.62 & 31.09 & Zhongxiang \\
\hline 5 & Shrubland & 113.21 & 30.89 & Jingshan \\
\hline 6 & Shrubland & 113.21 & 30.88 & Jingshan \\
\hline 7 & Shrubland & 113.21 & 30.88 & Jingshan \\
\hline 8 & Pond & 113.27 & 30.83 & Tianmen \\
\hline 9 & open woodland & 113.27 & 30.83 & Tianmen \\
\hline 10 & open woodland & 113.26 & 30.82 & Tianmen \\
\hline 11 & River & 113.51 & 30.80 & Yingcheng \\
\hline 12 & River & 113.51 & 30.77 & Yingcheng \\
\hline 13 & Pond & 113.70 & 30.62 & Hanchuan \\
\hline 14 & River & 113.64 & 30.57 & Hanchuan \\
\hline 15 & River & 113.64 & 30.55 & Hanchuan \\
\hline 16 & Pond & 112.66 & 30.61 & Qianjiang \\
\hline 17 & River & 113.64 & 30.54 & Hanchuan \\
\hline 18 & River & 112.66 & 30.61 & Qianjiang \\
\hline 19 & Beach land & 111.96 & 30.64 & Dangyang \\
\hline 20 & River & 112.55 & 30.59 & Shayang \\
\hline 21 & River & 113.61 & 30.50 & Hanchuan \\
\hline 22 & River & 112.57 & 30.56 & Shayang \\
\hline 23 & Irrigated land & 112.57 & 30.55 & Shayang \\
\hline 24 & Paddy filed & 113.64 & 30.43 & Hanchuan \\
\hline 25 & Irrigated land & 113.63 & 30.43 & Hanchuan \\
\hline 26 & River & 113.34 & 30.43 & Xiantao \\
\hline 27 & River & 112.86 & 30.46 & Qianjiang \\
\hline 28 & River & 113.26 & 30.43 & Xiantao \\
\hline 29 & Beach land & 112.86 & 30.46 & Qianjiang \\
\hline 30 & Paddy filed & 113.61 & 30.40 & Xiantao \\
\hline 31 & Paddy filed & 113.60 & 30.40 & Xiantao \\
\hline 32 & River & 113.39 & 30.41 & Xiantao \\
\hline 33 & River & 113.47 & 30.39 & Xiantao \\
\hline 34 & River & 113.47 & 30.39 & Xiantao \\
\hline 35 & River & 113.47 & 30.39 & Xiantao \\
\hline 36 & River & 113.45 & 30.39 & Tianmen \\
\hline 37 & River & 113.47 & 30.39 & Xiantao \\
\hline 38 & Lake & 112.25 & 30.46 & Jingzhou \\
\hline 39 & River & 112.84 & 30.41 & Qianjiang \\
\hline 40 & Irrigated land & 112.81 & 31.19 & Zhongxiang \\
\hline
\end{tabular}

Table A3. Information about top 40 barriers.

\begin{tabular}{ccccc}
\hline Rank & Land Cover Type & Latitude & Longitude & County \\
\hline 1 & Paddy filed & 113.26 & 31.20 & Jingshan \\
2 & Rural construction land & 112.61 & 31.10 & Zhongxiang \\
3 & Rural construction land & 112.61 & 31.10 & Zhongxiang \\
4 & Paddy filed & 112.61 & 31.10 & Zhongxiang \\
5 & Mine & 112.62 & 31.10 & Zhongxiang \\
6 & Paddy filed & 112.61 & 31.10 & Zhongxiang \\
\hline
\end{tabular}


Table A3. Cont.

\begin{tabular}{|c|c|c|c|c|}
\hline Rank & Land Cover Type & Latitude & Longitude & County \\
\hline 7 & Rural construction land & 112.61 & 31.10 & Zhongxiang \\
\hline 8 & Rural construction land & 112.61 & 31.10 & Zhongxiang \\
\hline 9 & Rural construction land & 112.61 & 31.10 & Zhongxiang \\
\hline 10 & Rural construction land & 112.61 & 31.10 & Zhongxiang \\
\hline 11 & Rural construction land & 112.61 & 31.10 & Zhongxiang \\
\hline 12 & Paddy filed & 112.62 & 31.10 & Zhongxiang \\
\hline 13 & Urban construction land & 113.47 & 30.86 & Yingcheng \\
\hline 14 & Paddy filed & 113.70 & 30.74 & Hanchuan \\
\hline 15 & Rural construction land & 113.64 & 30.43 & Hanchuan \\
\hline 16 & Rural construction land & 113.64 & 30.43 & Hanchuan \\
\hline 17 & Paddy filed & 112.14 & 30.45 & Jingzhou \\
\hline 18 & Rural construction land & 113.60 & 30.34 & Xiantao \\
\hline 19 & Rural construction land & 113.60 & 30.34 & Xiantao \\
\hline 20 & Mine & 113.49 & 30.33 & Xiantao \\
\hline 21 & Mine & 113.50 & 30.33 & Xiantao \\
\hline 22 & Mine & 113.50 & 30.33 & Xiantao \\
\hline 23 & Mine & 113.50 & 30.33 & Xiantao \\
\hline 24 & Mine & 113.50 & 30.33 & Xiantao \\
\hline 25 & Mine & 113.50 & 30.33 & Xiantao \\
\hline 26 & Mine & 113.51 & 30.33 & Xiantao \\
\hline 27 & Mine & 113.51 & 30.33 & Xiantao \\
\hline 28 & Mine & 113.52 & 30.33 & Xiantao \\
\hline 29 & Mine & 113.52 & 30.33 & Xiantao \\
\hline 30 & Paddy filed & 113.23 & 30.09 & Honghu \\
\hline 31 & Paddy filed & 112.36 & 30.08 & Jiangling \\
\hline 32 & Rural construction land & 112.37 & 30.08 & Jiangling \\
\hline 33 & Rural construction land & 112.37 & 30.08 & Jiangling \\
\hline 34 & Rural construction land & 112.37 & 30.08 & Jiangling \\
\hline 35 & Mine & 112.36 & 30.07 & Jiangling \\
\hline 36 & Mine & 112.37 & 30.07 & Jiangling \\
\hline 37 & Rural construction land & 111.91 & 29.88 & Gongan \\
\hline 38 & Paddy filed & 112.19 & 29.69 & Gongan \\
\hline 39 & Paddy filed & 112.38 & 29.63 & Shishou \\
\hline 40 & Mine & 113.24 & 31.20 & Jingshan \\
\hline
\end{tabular}

\section{References}

1. Knaapen, J.P.; Scheffer, M.; Harms, B. Estimating Habitat Isolation in Landscape Planning. Landsc. Urban Plan. 1992, 23, 1-16. [CrossRef]

2. Aronson, J.; Clewell, A.F.; Blignaut, J.N.; Milton, S.J. Ecological Restoration: A New Frontier for Nature Conservation and Economics. J. Nat. Conserv. 2006, 14, 135-139. [CrossRef]

3. Cao, S.; Xia, C.; Suo, X.; Wei, Z. A Framework for Calculating the Net Benefits of Ecological Restoration Programs in China. Ecosyst. Serv. 2021, 50, 101325. [CrossRef]

4. Liu, Y.; Zhou, Y. Territory Spatial Planning and National Governance System in China. Land Use Policy 2021, 102, 105288. [CrossRef]

5. Kang, J.; Zhang, X.; Zhu, X.; Zhang, B. Ecological Security Pattern: A New Idea for Balancing Regional Development and Ecological Protection. A Case Study of the Jiaodong Peninsula, China. Glob. Ecol. Conserv. 2021, 26, e01472. [CrossRef]

6. Jongman, R.H.G. Nature Conservation Planning in Europe: Developing Ecological Networks. Landsc. Urban Plan. 1995, 32, 169-183. [CrossRef]

7. Fábos, J.G. Greenway Planning in the United States: Its Origins and Recent Case Studies. Landsc. Urban Plan. 2004, 68, 321-342. [CrossRef]

8. Peng, J.; Zhao, H.; Liu, Y. Urban Ecological Corridors Construction: A Review. Acta Ecol. Sin. 2017, 37, 23-30. [CrossRef]

9. Wang, C.; Yu, C.; Chen, T.; Feng, Z.; Hu, Y.; Wu, K. Can the Establishment of Ecological Security Patterns Improve Ecological Protection? An Example of Nanchang, China. Sci. Total. Environ. 2020, 740, 140051. [CrossRef] [PubMed]

10. Jongman, R.H.G.; Külvik, M.; Kristiansen, I. European Ecological Networks and Greenways. Landsc. Urban Plan. 2004, 68, 305-319. [CrossRef] 
11. Modica, G.; Praticò, S.; Laudari, L.; Ledda, A.; Di Fazio, S.; De Montis, A. Implementation of Multispecies Ecological Networks at the Regional Scale: Analysis and Multi-Temporal Assessment. J. Environ. Manag. 2021, 289, 112494. [CrossRef] [PubMed]

12. Gurrutxaga, M.; Rubio, L.; Saura, S. Key Connectors in Protected Forest Area Networks and the Impact of Highways: A Transnational Case Study from the Cantabrian Range to the Western Alps (SW Europe). Landsc. Urban Plan. 2011, 101, 310-320. [CrossRef]

13. Delnevo, N.; van Etten, E.J.; Byrne, M.; Petraglia, A.; Carbognani, M.; Stock, W.D. Habitat Fragmentation Restricts Insect Pollinators and Pollen Quality in a Threatened Proteaceae Species. Biol. Conserv. 2020, 252, 108824. [CrossRef]

14. Fichera, C.R.; Laudari, L.; Modica, G. Application, Validation and Comparison in Different Geographical Contexts of an Integrated Model for the Design of Ecological Networks. J. Agric. Eng. 2013, 46, 52-61. [CrossRef]

15. Gurrutxaga, M.; Lozano, P.J.; del Barrio, G. GIS-Based Approach for Incorporating the Connectivity of Ecological Networks into Regional Planning. J. Nat. Conserv. 2010, 18, 318-326. [CrossRef]

16. Pascual-Hortal, L.; Saura, S. Integrating Landscape Connectivity in Broad-Scale Forest Planning through a New Graph-Based Habitat Availability Methodology: Application to Capercaillie (Tetrao Urogallus) in Catalonia (NE Spain). Eur. J. For. Res. 2008, 127, 23-31. [CrossRef]

17. Dallat, M.A.T.; Soerjomataram, I.; Hunter, R.F.; Tully, M.A.; Cairns, K.J.; Kee, F. Urban Greenways Have the Potential to Increase Physical Activity Levels Cost-Effectively. Eur. J. Public Health 2014, 24, 190-195. [CrossRef]

18. Gobster, P.H.; Westphal, L.M. The Human Dimensions of Urban Greenways: Planning for Recreation and Related Experiences. Landsc. Urban Plan. 2004, 68, 147-165. [CrossRef]

19. Librett, J.J.; Yore, M.M.; Schmid, T.L. Characteristics of Physical Activity Levels Among Trail Users in a U.S. National Sample. Am. J. Prev. Med. 2006, 31, 399-405. [CrossRef] [PubMed]

20. Larson, L.R.; Keith, S.J.; Fernandez, M.; Hallo, J.C.; Shafer, C.S.; Jennings, V. Ecosystem Services and Urban Greenways: What's the Public's Perspective? Ecosyst. Serv. 2016, 22, 111-116. [CrossRef]

21. Shafer, C.S.; Lee, B.K.; Turner, S. A Tale of Three Greenway Trails: User Perceptions Related to Quality of Life. Landsc. Urban Plan. 2000, 49, 163-178. [CrossRef]

22. Keith, S.J.; Larson, L.R.; Shafer, C.S.; Hallo, J.C.; Fernandez, M. Greenway Use and Preferences in Diverse Urban Communities: Implications for Trail Design and Management. Landsc. Urban Plan. 2018, 172, 47-59. [CrossRef]

23. Elliot, T.; Bertrand, A.; Babí Almenar, J.; Petucco, C.; Proença, V.; Rugani, B. Spatial Optimisation of Urban Ecosystem Services through Integrated Participatory and Multi-Objective Integer Linear Programming. Ecol. Model. 2019, 409, 108774. [CrossRef]

24. Fisher, B.; Turner, R.K.; Morling, P. Defining and Classifying Ecosystem Services for Decision Making. Ecol. Econ. 2009, 68, 643-653. [CrossRef]

25. Gómez-Betancur, L.; Vilardy, Q.S.P.; Torres, R.D. Ecosystem Services as a Promising Paradigm to Protect Environmental Rights of Indigenous Peoples in Latin America: The Constitutional Court Landmark Decision to Protect Arroyo Bruno in Colombia. Environ. Manag. 2021. [CrossRef]

26. Lin, Y.-P.; Lin, W.-C.; Wang, Y.-C.; Lien, W.-Y.; Huang, T.; Hsu, C.-C.; Schmeller, D.S.; Crossman, N.D. Systematically Designating Conservation Areas for Protecting Habitat Quality and Multiple Ecosystem Services. Environ. Model. Softw. 2017, 90, 126-146. [CrossRef]

27. Burgos-Ayala, A.; Jiménez-Aceituno, A.; Rozas-Vásquez, D. Integrating Ecosystem Services in Nature Conservation for Colombia. Environ. Manag. 2020, 66, 149-161. [CrossRef]

28. Burkhard, B.; Kroll, F.; Nedkov, S.; Müller, F. Mapping Ecosystem Service Supply, Demand and Budgets. Ecol. Indic. 2012, 21, 17-29. [CrossRef]

29. Babí Almenar, J.; Bolowich, A.; Elliot, T.; Geneletti, D.; Sonnemann, G.; Rugani, B. Assessing Habitat Loss, Fragmentation and Ecological Connectivity in Luxembourg to Support Spatial Planning. Landsc. Urban Plan. 2019, 189, 335-351. [CrossRef]

30. Serna-Chavez, H.M.; Schulp, C.J.E.; van Bodegom, P.M.; Bouten, W.; Verburg, P.H.; Davidson, M.D. A Quantitative Framework for Assessing Spatial Flows of Ecosystem Services. Ecol. Indic. 2014, 39, 24-33. [CrossRef]

31. Palomo, I.; Martín-López, B.; Potschin, M.; Haines-Young, R.; Montes, C. National Parks, Buffer Zones and Surrounding Lands: Mapping Ecosystem Service Flows. Ecosyst. Serv. 2013, 4, 104-116. [CrossRef]

32. Wang, Z.; Shi, P.; Zhang, X.; Tong, H.; Zhang, W.; Liu, Y. Research on Landscape Pattern Construction and Ecological Restoration of Jiuquan City Based on Ecological Security Evaluation. Sustainability 2021, 13, 5732. [CrossRef]

33. Peng, J.; Zhao, H.; Liu, Y.; Xu, J. Research Progress and Prospect on Regional Ecological Security Pattern Construction. Geogr. Res. 2017, 36, 407-417. [CrossRef]

34. Yuan, W.; Chang-wei, Z. Landscape Ecological Security Pattern in Central Guizhou Urban Agglomeration. J. Ecol. Rural. Environ. 2019, 35, 1111-1117. [CrossRef]

35. Peng, J.; Yang, Y.; Liu, Y.; Hu, Y.; Du, Y.; Meersmans, J.; Qiu, S. Linking Ecosystem Services and Circuit Theory to Identify Ecological Security Patterns. Sci. Total. Environ. 2018, 644, 781-790. [CrossRef] [PubMed]

36. Yang, S.-S.; Zou, C.-X.; Shen, W.-S.; Shen, R.-P.; Xu, D.-L. Construction of Ecological Security Patterns Based on Ecological Red Line: A Case Study of Jiangxi Province. GEOGRAPHICAL RESEARCH 2016, 35, 250-258. [CrossRef]

37. Jiang, H.; Peng, J.; Dong, J.; Zhang, Z.; Xu, Z.; Meersmans, J. Linking Ecological Background and Demand to Identify Ecological Security Patterns across the Guangdong-Hong Kong-Macao Greater Bay Area in China. Landsc. Ecol. 2021, 36, $2135-2150$. [CrossRef] 
38. Liu, Y.; Cui, N.; Han, R.; Guo, L. Establishing Ecological Security Patterns Based on Reconstructed Ecosystem Services Value in Rapidly Urbanizing Areas: A Case Study in Zhuhai City, China. Sustainability 2020, 12, 6629. [CrossRef]

39. Gao, M.; Hu, Y.; Li, X.; Song, R. Construction of Ecological Security Pattern based on the Importance of Ecosystem Services and Environmental Sensitivity in Karst Mountainous Areas: A Case Study in Hechi, Guangxi. Acta Ecol. Sin. 2021, 41. [CrossRef]

40. Hepcan, Ç.C.; Özkan, M.B. Establishing Ecological Networks for Habitat Conservation in the Case of Çeşme-Urla Peninsula, Turkey. Environ. Monit. Assess. 2011, 174, 157-170. [CrossRef]

41. Kong, F.; Yin, H.; Nakagoshi, N.; Zong, Y. Urban Green Space Network Development for Biodiversity Conservation: Identification Based on Graph Theory and Gravity Modeling. Landsc. Urban Plan. 2010, 95, 16-27. [CrossRef]

42. Gao, Y.; Liu, Y.; Qian, J.; Guo, Y.; Hu, Y. Improving Ecological Security Pattern Based on the Integrated Observation of Multiple Source Data: A Case Study of Wannian County, Jiangxi Province. Resour. Sci. 2020, 40, 2010-2021. [CrossRef]

43. Vigerstol, K.L.; Aukema, J.E. A Comparison of Tools for Modeling Freshwater Ecosystem Services. J. Environ. Manag. 2011, 92, 2403-2409. [CrossRef] [PubMed]

44. Jin, X.; Wei, L.; Wang, Y.; Lu, Y. Construction of Ecological Security Pattern Based on the Importance of Ecosystem Service Functions and Ecological Sensitivity Assessment: A Case Study in Fengxian County of Jiangsu Province, China. Environ. Dev. Sustain. 2021, 23, 563-590. [CrossRef]

45. Gao, L.; Ma, C.; Wang, Q.; Zhou, A. Sustainable Use Zoning of Land Resources Considering Ecological and Geological Problems in Pearl River Delta Economic Zone, China. Sci. Rep. 2019, 9, 16052. [CrossRef]

46. Wang, W.; Feng, C.; Liu, F.; Li, J. Biodiversity Conservation in China: A Review of Recent Studies and Practices. Environ. Sci. Ecotechnol. 2020, 2, 100025. [CrossRef]

47. Ministry of Ecology and Environment. China National Biodiversity Conservation Strategy and Action Plan (2011-2030); Ministry of Ecology and Environment: Beijing, China, 2010.

48. Lai, Y.; Huang, G.; Chen, S.; Lin, S.; Lin, W.; Lyu, J. Land Use Dynamics and Optimization from 2000 to 2020 in East Guangdong Province, China. Sustainability 2021, 13, 3473. [CrossRef]

49. Yin, J.; Li, H.; Wang, D.; Liu, S. Optimization of Rural Settlement Distributions Based on the Ecological Security Pattern: A Case Study of Da'an City in Jilin Province of China. Chin. Geogr. Sci. 2020, 30, 824-838. [CrossRef]

50. Ouyang, X.; Wang, Z.; Zhu, X. Construction of the Ecological Security Pattern of Urban Agglomeration under the Framework of Supply and Demand of Ecosystem Services Using Bayesian Network Machine Learning: Case Study of the Changsha-ZhuzhouXiangtan Urban Agglomeration, China. Sustainability 2019, 11, 6416. [CrossRef]

51. Jia, R.; Gao, R.; Ru, W.; Kong, D.; Ji, Z.; Zhang, G. Using Satellite Tracking to Identify the Factors Affecting the Spring Migration Timing of Whooper Swans (Cygnus Cygnus). Acta Ecol. Sin. 2021, 15. [CrossRef]

52. Gibbs, J. Wetland Loss and Biodiversity Conservation. Conserv. Biol. 2000, 14, 314-317. [CrossRef]

53. Tong, H.; Shi, P. Using Ecosystem Service Supply and Ecosystem Sensitivity to Identify Landscape Ecology Security Patterns in the Lanzhou-Xining Urban Agglomeration, China. J. Mt. Sci. 2020, 17, 2758-2773. [CrossRef]

54. Hu, Q.; Chen, S. Optimizing the Ecological Networks Based on the Supply and Demand of Ecosystem Services in XiamenZhangzhou-Quanzhou Region. J. Nat. Resour. 2021, 2, 342-355. [CrossRef]

55. Parks, S.A.; Mckelvey, K.S.; Schwartz, M.K. Effects of Weighting Schemes on the Identification of Wildlife Corridors Generated with Least-Cost Methods. Conserv. Biol. 2013, 27, 145-154. [CrossRef] [PubMed]

56. Dickson, B.; Albano, C.; Gray, M.; McClure, M.; Theobald, D.; Anantharaman, R.; Shah, V.; Beier, P.; Fargione, J.; Hall, K.; et al. Circuit-Theory Applications to Connectivity Science and Conservation. Conserv. Biol. 2018, 33. [CrossRef] [PubMed]

57. Koh, I.; Rowe, H.; Holland, J. Graph and Circuit Theory Connectivity Models of Conservation Biological Control Agents. Ecol. Appl. 2013, 23, 1554-1573. [CrossRef]

58. Urban, D.; Keitt, T. Landscape Connectivity: A Graph-Theoretic Perspective. Ecology 2001, 82, 1205-1218. [CrossRef]

59. Sawyer, S.C.; Epps, C.W.; Brashares, J.S. Placing Linkages among Fragmented Habitats: Do Least-Cost Models Reflect How Animals Use Landscapes? J. Appl. Ecol. 2011, 48, 668-678. [CrossRef]

60. LaPoint, S.; Gallery, P.; Wikelski, M.; Kays, R. Animal Behavior, Cost-Based Corridor Models, and Real Corridors. Landsc. Ecol. 2013, 28, 1615-1630. [CrossRef]

61. McRae, B.; Dickson, B.; Keitt, T.; Shah, V.; McRae, B.H.; Dickson, B.G.; Keitt, T.H.; Shah, V.B. Using Circuit Theory to Model Connectivity in Ecology, Evolution, and Conservation. Ecology 2008, 89, 2712-2724. [CrossRef]

62. Hanks, E.; Hooten, M. Circuit Theory and Model-Based Inference for Landscape Connectivity. J. Am. Stat. Assoc. 2013, 108. [CrossRef]

63. Christensen, A.; Brandt, J.; Svenningsen, S. Landscape Ecology; Springer: Berlin, Germany, 2017; pp. 1-10. ISBN 978-0-470-65963-2.

64. McRae, B.; Shah, V. Circuitscape User Guide; The University of California: Santa Barbara, CA, USA, 2009.

65. Islam, M.S.; Quinn, M. A Composite Graph Theoretic Approach to Modeling Landscape Connectivity for Wildlife Movement in Western Canada. J. Environ. Inform. Lett. 2021. [CrossRef]

66. Gong, S. Historical Variation and Sustainable Utilization of the Jianghan-Dongting Plain's Wetlands. Resour. Environ. Yangtze Basin 2002, 11, 569-574.

67. Chen, S.; Pi, M. Old News of Hubei; Wuhan Press: Wuhan, China, 1989; ISBN 978-7-5430-0293-7.

68. He, Y. Historical Changes of Rare Animals in China; Hunan Normal University Press: Hunan, China, 1997; Volume 2, ISBN 978-781031-580-7. 
69. Lu, W. Current Status and Conservation Countermeasures for National Grade I Protected Wildlife Fauna in Hubei Province. Hubei For. Sci. Technol. 2007, 54-58.

70. Jiang, Z.; Liu, S.; Wu, Y.; Jiang, X.; Zhou, K. China's Mammal Diversity (2nd Edition). Biodivers. Sci. 2017, 8, 886-895. [CrossRef]

71. Dai, Z.; Zhang, H.; Zhou, Q.; Liu, X. Amphibian Resources in Hubei Province. Sichuan J. Zool. 2011, 30, 144-147. [CrossRef]

72. Scientific Data.

73. Harmonized World Soil Database v1.2 I FAO SOILS PORTAL I Food and Agriculture Organization of the United Nations. Available online: http:/ / www.fao.org/soils-portal/data-hub/soil-maps-and-databases/harmonized-world-soil-database-v12/en/ (accessed on 6 August 2021).

74. Resources and Environmental Science Data Center.

75. Meteorological Data Center of China Meteorological Administration 2021.

76. The Shuttle Radar Topography Mission.

77. Yu, K. Security Patterns and Surface Model in Landscape Ecological Planning. Landsc. Urban Plan. 1996, 36, 1-17. [CrossRef]

78. Wang, S.; Wu, M.; Hu, M.; Fan, C.; Wang, T.; Xia, B. Promoting Landscape Connectivity of Highly Urbanized Area: An Ecological Network Approach. Ecol. Indic. 2021, 125, 107487. [CrossRef]

79. Samways, M.J.; Bazelet, C.S.; Pryke, J.S. Provision of Ecosystem Services by Large Scale Corridors and Ecological Networks. Biodivers. Conserv. 2010, 19, 2949-2962. [CrossRef]

80. Liquete, C.; Kleeschulte, S.; Dige, G.; Maes, J.; Grizzetti, B.; Olah, B.; Zulian, G. Mapping Green Infrastructure Based on Ecosystem Services and Ecological Networks: A Pan-European Case Study. Environ. Sci. Policy 2015, 54, 268-280. [CrossRef]

81. Haaren, C.; Lovett, A.; Albert, C. Theories and Methods for Ecosystem Services Assessment in Landscape Planning; Springer: Berlin, Germany, 2019; pp. 19-42. ISBN 978-94-024-1679-4.

82. Thoresen, J.; Vermeire, M.-L.; Venter, Z.; Wolfaard, G.; Krumins, J.A.; Cramer, M.; Hawkins, H.-J. Fire and Herbivory Shape Soil Arthropod Communities through Habitat Heterogeneity and Nutrient Cycling in Savannas. Glob. Ecol. Conserv. 2021, 25 , e01413. [CrossRef]

83. Li, Q.; Zhou, Y.; Mary Ann, C.; Xu, T. Spatio-Temporal Changes in Wildlife Habitat Quality in the Middle and Lower Reaches of the Yangtze River from 1980 to 2100 Based on the InVEST Model. J. Resour. Ecol. 2021, 12, 43-55. [CrossRef]

84. Nelson, E.; Polasky, S.; Lewis, D.J.; Plantinga, A.J.; Lonsdorf, E.; White, D.; Bael, D.; Lawler, J.J. Efficiency of Incentives to Jointly Increase Carbon Sequestration and Species Conservation on a Landscape. Proc. Natl. Acad. Sci. USA 2008, 105, 9471-9476. [CrossRef]

85. Wang, R.; Li, C. Spatiotemporal Analysis of Precipitation Trends during 1961-2010 in Hubei Province, Central China. Theor. Appl. Climatol. 2016, 124, 385-399. [CrossRef]

86. Lu, F.; hu, H.; Sun, W.; Zhu, J.; Liu, G.; Zhou, W.; Zhang, Q.; Shi, P.; Liu, X.; Wu, X.; et al. Effects of National Ecological Restoration Projects on Carbon Sequestration in China from 2001 to 2010. Proc. Natl. Acad. Sci. USA 2018, 115, 4039-4044. [CrossRef]

87. Wu, J.; Wang, C.; Du, H.; Liu, Z.; Shen, L.; Wei, Q.; Rosenthal, H. Drastic Decline in Spawning Activity of Chinese Sturgeon Acipenser Sinensis Gray 1835 in the Remaining Spawning Ground of the Yangtze River since the Construction of Hydrodams. J. Appl. Ichthyol. 2015, 31. [CrossRef]

88. Li, B.; Chen, N.; Wang, W.; Wang, C.; Schmitt, R.J.P.; Lin, A.; Daily, G.C. Eco-Environmental Impacts of Dams in the Yangtze River Basin, China. Sci. Total. Environ. 2021, 774, 145743. [CrossRef] [PubMed]

89. Department of Ecology and Environment of Hubei Province. Hubei Nature Reserve List; Department of Ecology and Environment of Hubei Province: Hubei, China, 2018.

90. Zhang, X.; Guo, Q.; Shen, X.; Yu, S.; Qiu, G. Water Quality, Agriculture and Food Safety in China: Current Situation, Trends, Interdependencies, and Management. J. Integr. Agric. 2015, 14, 2365-2379. [CrossRef]

91. Sharp, R.; Chaplin-Kramer, R.; Wood, S.; Guerry, A.; Tallis, H.; Ricketts, T.; Nelson, E.; Ennaanay, D.; Wolny, S.; Olwero, N.; et al. VEST User's Guide; McGill University: Montreal, QC, Canada, 2018.

92. Yang, D.; Liu, W.; Tang, L.; Chen, L.; Li, X.; Xu, X. Estimation of Water Provision Service for Monsoon Catchments of South China: Applicability of the InVEST Model. Landsc. Urban Plan. 2019, 182, 133-143. [CrossRef]

93. Xiao, S.; Wu, W.; Guo, J.; Ou, M.; Pueppke, S.G.; Ou, W.; Tao, Y. An Evaluation Framework for Designing Ecological Security Patterns and Prioritizing Ecological Corridors: Application in Jiangsu Province, China. Landsc. Ecol. 2020, 35, $2517-2534$. [CrossRef]

94. Yimin, L.; Guan, C.; Zhu, J. GIS-Based Ecological Sensitivity Analysis in Xingyun Lake Basin. Res. Soil Water Conserv. 2017, 24, 266-271.

95. Borrelli, P.; Alewell, C.; Alvarez, P.; Anache, J.A.A.; Baartman, J.; Ballabio, C.; Bezak, N.; Biddoccu, M.; Cerdà, A.; Chalise, D.; et al. Soil Erosion Modelling: A Global Review and Statistical Analysis. Sci. Total. Environ. 2021, 780, 146494. [CrossRef]

96. Li, F.; Guo, S.; Li, D.; Li, X.; Li, J.; Xie, S. A Multi-Criteria Spatial Approach for Mapping Urban Ecosystem Services Demand. Ecol. Indic. 2020, 112, 106119. [CrossRef]

97. Liu, B.; Xie, Y.; Li, Z.; Liang, Y.; Zhang, W.; Fu, S.; Yin, S.; Wei, X.; Zhang, K.; Wang, Z.; et al. The Assessment of Soil Loss by Water Erosion in China. Int. Soil Water Conserv. Res. 2020, 8, 430-439. [CrossRef] 
98. Blair, C.; J. Michael, S.; Michael, E.S.; Keith, H.; Larry, H. Landscape Linkages and Biodiversity; Island Press: Washington, DC, USA, 1991; ISBN 978-1-59726-868-4.

99. Harris, L.D.; Scheck, J. From Implications to Applications: The Dispersal Corridor Principle Applied to the Conservation of Biological Diversity. In Nature Conservation 2: The Role of Corridors; Saunders, D.A., Hobbs, R.J., Eds.; Surrey Beaty and Sons: Chipping Norton, Australia; pp. 189-220.

100. Zhang, H.; Gao, J.; Ma, M.; Shao, F.; Wang, Q.; Li, G.; Qiu, J.; Zhou, K. Influence of Road on Breeding Habitat of Nipponia Nippon Based on MaxEnt Model. Chin. J. Appl. Ecol. 2017, 28, 1352-1359. [CrossRef]

101. Zhu, Q.; Yu, K.; Li, D. The Width of Ecological Corridor in Landscape Planning. Acta Ecol. Sin. 2005, 9, $2406-2412$.

102. Zhao, X.; Yue, Q.; Pei, J.; Pu, J.; Huang, P.; Wang, Q. Ecological Security Pattern Construction in Karst Area Based on Ant Algorithm. Int. J. Environ. Res. Public Health 2021, 18, 6863. [CrossRef] [PubMed]

103. Tang, L.; Ke, X.; Zhou, T.; Zheng, W.; Wang, L. Impacts of Cropland Expansion on Carbon Storage: A Case Study in Hubei, China. J. Environ. Manag. 2020, 265, 110515. [CrossRef]

104. Gao, Y.; Li, H. Influence of Landscape Pattern Change on Soil Erosion in Han River Basin. Acta Ecol. Sin. 2021, 6, 2248-2260. [CrossRef]

105. Rayfield, B.; Fortin, M.-J.; Fall, A. The Sensitivity of Least-Cost Habitat Graphs to Relative Cost Surface Values. Landsc. Ecol. 2010, 25, 519-532. [CrossRef] 